\title{
Strategic Violence during Democratization: Evidence from Myanmar
}

\author{
Darin Christensen, Mai Nguyen $^{\ddagger}$ and Renard Sexton ${ }^{\S}$
}

July 17, 2018

\begin{abstract}
Democratic transitions are often followed by conflict. In this paper we explore one explanation for this fighting: the military's strategic use of violence to retain control of economically valuable regions. We find evidence of this dynamic in Myanmar, a country transitioning from four decades of military rule. Fearing that the new civilian government will assert authority over jade mining, the military initiates violence in mining townships to deter civilian control. Using geocoded data on conflict and jade mines, we find support for this argument: as Myanmar starts to transition in 2011, we observe a sharp increase in conflicts involving the military in jademining areas. We address alternative explanations, including a nationwide shift in the military's strategy, the co-location of mines and military headquarters, commodity prices, opposition to a controversial dam, and trends specific to Kachin State. We substantiate the theoretical claim that outgoing generals use instability to retain rents - a winning strategy where plausible challenges to state authority provide pretense for asserting military control over lucrative territory.
\end{abstract}

\footnotetext{
*We are grateful to James Fearon, Tarek Ghani, Guy Grossman, Chad Hazlett, Amy Liu, Eric Min, Tom Pepinsky, Jacob Shapiro, and audiences at SEAREG 2017, EPSA 2017, MPSA 2016, APSA 2017, and NYU for comments on earlier drafts. We would also like to thank Global Witness for generously sharing their data and feedback. All errors are our own.

${ }^{\dagger}$ Assistant Professor of Public Policy and Political Science, UCLA. e: darinc@luskin.ucla.edu. p: (310) 825-7196. UCLA Luskin School of Public Affairs, 337 Charles E. Young Dr. East, Los Angeles, CA 90095-1656.

${ }^{\ddagger}$ New York University. e: mai .nguyen@nyu . edu.

${ }^{\S}$ Postdoctoral Fellow, Princeton University. e: rsexton@princeton .edu.
} 
Violence commonly follows the handover of power from military dictators to democrats: over 40 percent of governments undergoing this transition become embroiled in internal violence within five years (Geddes, Wright, and Frantz 2014; Lacina and Gleditsch 2005). What explains the coincidence of democratization and violence?

One explanation relates to how military leaders use violence to retain control. In this paper, we examine the role of the military and the strategies it pursues to protect rents in the midst of a democratic transition. We argue that military elites face a perverse incentive to stir up conflict in economically valuable areas, so as to prevent new civilian leaders from asserting control.

During regime transitions civilian leaders must decide what to do with the old guard. Although a new civilian government may want to curtail the role of generals, it both relies on security forces to maintain order and risks a coup if it attempts to strip soldiers of authority and status. The military's cache of arms and ongoing role in national defense, thus, provide it with bargaining power during a transition to democracy (O'Donnell et al. 1986b). As Linz and Stepan $(1996,150)$ observe, military leaders do not eagerly cede political control, but rather "negotiate their withdrawal," attempting to maximize their "non-democratic prerogatives." These prerogatives can take the form of rents, political influence, or formal roles within the new administration. To further amplify its bargaining power and expand these prerogatives, the military has an incentive to convey - even exaggerate its role in protecting the nascent civilian government from internal and external threats.

To assess whether this prediction matches reality, we focus attention on a recent transition from military rule to democracy: Myanmar. We find evidence that Myanmar's ${ }^{1}$ military (known as the Tatmadaw) selectively stokes conflict to retain nondemocratic prerogatives, specifically its stake in the country's jade-mining sector. ${ }^{2}$ By some estimates, Myanmar's jade sector was worth up to 31 billion USD in 2014, equivalent to roughly half of the country's GDP (Global Witness 2015).

${ }^{1}$ Burma was renamed Myanmar in 1989. We use Burma to refer to the country before 1989 and Myanmar thereafter.

${ }^{2}$ We interchange the phrases Tatmadaw, Myanmar Armed Forces, and Myanmar's military. 
We argue that the Tatmadaw's leadership, which has well-documented ties to jade production and smuggling, initiated violence in mining areas during and after the transition, so as to deter the civilian government from directly administering these regions.

Using geocoded data on conflict and the locations of jade mines, we find support for this argument: just as Myanmar embarks on its political transition, inaugurating a new civilian government in 2011, we observe a sharp increase in conflicts involving government security forces in jade-mining areas. We find no corresponding spike in townships without jade mines. Primary and secondary sources indicate that this violence represents a Tatmadaw offensive in the jade-mining areas designed to protect rents flowing to military commanders. In an exemplary report on Myanmar's jade sector Global Witness $(2015,90)$ observes, "As with war economies the world over, genuine peace and outright war are the main enemies of the military entrepreneur in [the jade-mining areas of] Kachin State. Far preferable are the grey areas in between that justify the deployment of the troops needed to intimidate and extort but do not demand much actual fighting."

We bolster this conclusion by ruling out alternative explanations for the violence. For example, the increase in conflict does not represent a broader confrontation between the military and rebel groups (e.g., due to a change in the perceived strength of the Tatmadaw): of the 57 townships covered by ceasefire arrangements between the government and insurgent groups, violence only flares up in townships with jade mines. Furthermore, we do not observe increased conflict among ethnic armies or communal groups in jade-mining areas (or violence between military units). This suggests that the military is not reacting to instability, but rather initiating the violence. We also rule out commodity price changes, the controversial Myitsone Dam project, and trends specific to Kachin State as alternative accounts.

Research on democratization highlights the challenge of compensating incumbent elites who stand to lose from a transition to popular civilian control (O’Donnell et al. 1986b). These incumbents see the writing on the wall: once solidly in power, the ascendant democratic administration will strip them of their prior office-holding benefits (Acemoglu and Robinson 2006). We contribute to 
this literature by illustrating a strategy that military leaders deploy to forestall this loss of power and rents. Rather than quietly returning to the barracks, we argue that the military strategically uses violence to deter the new government from directly administering valuable territory, leaving control in the military's hands.

Earlier (almost exclusively) qualitative studies suggest that the dynamics we uncover in Myanmar generalize to other transitions (e.g., Finer 1962; O’Donnell et al. 1986b; Linz and Stepan 1996; Reno 1999). Juntas the world over resist the loss of rents implied by democratization. Under certain conditions, stoking violence can provide them a means of maintaining the existing system of protection and profit (Keen 2014). We expect this strategic dynamic to be present in contexts where a plausible challenge to state authority (e.g., an insurgent group like the Kachin Independence Army in Myanmar) can be used as a pretense for military intervention in, or administration of, valuable territory. These scope conditions are satisfied in a number of autocracies: we identify over two dozen autocratic regimes that encompass valuable but contested districts - operationalized here as sub-provincial administrative units where both mineral deposits and civil conflict coincide — such as Cameroon, Laos, Syria and Uzbekistan. ${ }^{3}$

Mining is not the only determinant of a territory's value. In Yemen, for example, separatist conflicts could provide grounds for military intervention in, and continued oversight of, oil and gas fields (Naylor 2015). Were a transition to occur, the Eritrean border conflict with Ethiopia could, for example, be used to justify military engagement along lucrative coffee trade corridors (Keller 2004). While we cannot speak to the durability of democratization - Myanmar remains at risk of a

${ }^{3}$ The strategic use of violence can also be deployed in more democratic contexts. Studies from Colombia (Fergusson et al. 2014) and India (Vanden Eynde 2015) show how incumbents counter-intuitively provoke or permit violence to maintain their control. And since 2017, military officers in Venezuela have been given increased control over the country's oil industry (Ulmer and Buitrago 2017). It is plausible that down the line the Venezuelan military could use the ongoing border clashes with Colombian forces as a pretense for stoking violence to protect their newly obtained rents. 
coup — the military's efforts to retain reserved domains hampers reform efforts. Diamond (1997, 30), remarking on the limits of liberalization in many "Third Wave" democracies, observes that "in a majority of countries the traditionally dominant sectors of society - political elites, the wealthy, armies, police - continue to enrich themselves at public expense... Voters can choose presidents and legislators through the ballot box in most countries, but government remains a racket dominated by the powerful and the well-connected." Examining how juntas use violence to maintain a grip on power clarifies the limits to reform and the tradeoff between democracy and stability.

\section{Background}

\subsection{Military Responses to Democratic Transitions}

During their reign, military leaders often assume wide-ranging control, "conquer[ing]," to use O’Donnell et al.'s $(1986 a, 11)$ language, “a broad range of issues and institutions.” For example, the military junta in Brazil (1964-85) established a set of state-owned enterprises, including the Embraer aircraft manufacturer and the Engesa engineering firm. In modern day Vietnam, the military owns and operates Viettel, which is the largest telecommunications firm in the country. In the case of Myanmar, jade mining constitutes a valuable part of the military's portfolio.

This control entitles military leaders to a steady stream of rents, which they are understandably reticent to relinquish. Geddes, Frantz, and Wright (2014) observe that military regimes more often avoid violent overthrows (relative to other autocracies) and instead carry out "managed transitions" that are intended to maintain cohesiveness and protect their privileges. In quietly "negotiating their withdrawal," to use Linz and Stepan's $(1996,150)$ terminology, these military elite attempt to maximize their "non-democratic prerogatives." The terms of these extrication pacts include promises of ongoing political and economic influence, including roles within the new administration (O’Donnell et al. 1986b; Przeworski 1991; Haggard and Kaufman 1995). For example, after the 1980 coup by the Turkish military, the junta successfully drafted a constitution that protected its privileges and kept military personnel in positions of authority within the next civilian administra- 
tion (Özbudun 2000). In Brazil in the 1980s, outgoing military officials were allowed to maintain control of state-owned industries in exchange for withdrawing from politics (Hagopian 1990).

In the course of negotiating the terms of a political transition, both military leaders and their civilian successors jockey to maximize their bargaining positions (O’Donnell et al. 1986b). ${ }^{4}$ The military's destructive capacity and ongoing role in national security provide obvious sources of leverage. As Finer $(1962,5)$ notes, "the political advantages of the military vis-a-vis other and civilian groupings are overwhelming. The military possess vastly superior organization. And they possess arms."

This bargaining power is only amplified by (threats of) internal or external conflicts. Recognizing the advantages of violence, incumbents "sustain war" to bolster their legitimacy or gain economic advantage (Smith 2007, 5). For example, the military junta of Argentina used the Falkland Islands dispute to rally public support; Greek military officials deployed a coup d'etat in Cyprus to overcome unpopularity at home. Violence can also be used in a targeted way to deter the new government from controlling valuable regions. Previewing our argument, we claim that Myanmar's military stoked violence in resource-rich regions to retain its control over the country's lucrative jade-mining sector.

Myanmar's military did not pioneer this strategy: India and Angola both provide examples of rebel violence being used as a pretense for resisting central government attempts to assert control over mining regions (Vanden Eynde 2015; Reno 1999). Describing the tactics of Angola's "wildcat miner generals," Reno $(1999,66)$ notes how they, "take advantage of chaos in mining areas to make their own deals with UNITA [rebel] miners or conquer turf for themselves...In fact, enterprising generals may see rebel attacks as a chance for them to take direct control over diamonds for personal

\footnotetext{
${ }^{4}$ This also speaks to one of the fundamental tensions in civil-military relations literature: the possibility of a coup. In order to fulfill its function the military must be strong enough to face its enemies and wield coercive power; however, increased power also means the potential for direct seizure of political control by the military (Huntington 1957; Janowitz 1961; Feaver 1996; Acemoglu, Ticchi, and Vindigni 2010).
} 
gain, which can also be done in collusion with rebels." Rather than representing collapse of political order, violence during a transition can be a way for the military to maintain its system of profit in the face of reforms (Keen 2014). Cross-national data on regime transitions (Geddes, Wright, and Frantz 2014) and intrastate conflict (Lacina and Gleditsch 2005) indicates that internal violence commonly follows transitions from military rule to democracy: we find that 41 percent of states ( 20 of 49 ) that make this transition experience internal violence involving the government within five years of the transition. Of those violent transitions, 75 percent of occur in countries that depend heavily on natural resources (greater than 10 percent of GDP in 2015).

This literature suggests two challenges associated with wresting political power from the military. First, the military is unlikely to fully relinquish control and return to the barracks. Consistent with a common finding in the literature on democratization, transitions are likely to be halting and incomplete. Second, political liberalization can provoke violence, generating a tradeoff between democracy and stability. ${ }^{5}$

\subsection{The Military's Past and Current Role in Burmese Politics}

Since its inception, the Burmese state has had to contend with numerous ethnic minority and communist insurgencies in the borderlands. In the decade after independence ethnic, political, and territorial tensions escalated, ${ }^{6}$ destabilizing the nascent Rangoon-based government (Callahan 2003). During this time the Tatmadaw emerged as the sole institution that was capable of establishing order and consolidating widespread authority (Callahan and Emmerson 1998). The civilian government relied on the army to fight insurgents and maintain some semblance of stability

${ }^{5}$ Unlike the cases of Indonesia or Romania, where competing factions within the security services clashed, Myanmar's military has generally remained unified in the face of armed ethnic organizations (Gledhill 2012). Indeed, we do not observe violence erupting among Myanmar's security services.

${ }^{6}$ In addition to internal conflict, the fledgling nation was forced to deal with the intrusion of Kuomintang troops in the northern border regions as they retreated from China. 
throughout the country. As such, the Tatmadaw undertook a significant structural transformation and built up its violent capacity resulting in "military aggrandizement of resources, responsibilities, and power in traditionally nonmilitary realms" (Callahan 2003,18). The development of military powers expanded into state-building and governing, eventually culminating in a 1962 coup and military rule. It was during this period that the Tatmadaw began to establish itself as the institution we know today. As Slater $(2014,175)$ notes, "it is the relative intensity and intractability of separatist insurgencies that Burma confronted between 1948 and 1962 that best explain why the Tatmadaw has exhibited so much more unity and so much greater will to power than its counterparts in South East Asia and beyond."

The military might of the Tatmadaw was solidified in 1988 when a second coup brought to power the State Law and Order Restoration Council (SLORC). Military rule under the SLORC, and later SDPC, was characterized by military expansion, the creation of military-owned economic enterprises, elevation of the role of regional commanders and ceasefire diplomacy. The new junta undertook a massive expansion of the armed forces, doubling the number of soldiers from 186,000 in 1988 to 370,000 in 1996 (Callahan 2003, 211). Additionally, over one billion dollars was spent on new equipment (e.g., combat aircraft, naval vessels, tanks, etc.).

The Tatmadaw's most economically lucrative sector has long been the jade trade, which is estimated to represent half the country's GDP. In addition to its major holdings in the gemstone sector, the Tatmadaw also earned revenues from banking, hotels and tourism, transportation, telecommunications and electronic equipment, construction, real estate, and automobiles (Myoe 2009, 178). Much of the revenue was funneled through two military-owned corporations, the Union of Myanmar Economic Holding, Ltd. (UMEHL) and Myanmar Economic Corporation (MEC), which after transition have remained under the control of the military hierarchy. Military leaders also charged a "whitening tax" on foreign exchange brought in by the opium and methamphetamine trades (Callahan 2003).

Often in the service of its economic operations, the military regime sought to alleviate conflict 
through the use of ceasefire diplomacy. Between 1989 and 1997, at least 17 ceasefires were negotiated with armed ethnic groups, including the United Wa State Party (UWSP), Shan State Army, and the Kachin Independence Organization (KIO) (Kyed and Gravers 2014; Jolliffe 2015). While these ceasefires rarely addressed the underlying political grievances of ethnic minority communities, they frequently established an economic partnership between the Tatmadaw and armed groups. As Callahan $(2003,19)$ notes: these ceasefire agreements were "nothing more than temporary, ad hoc answers to complex, centuries-old structural problems of state building in the regions beyond central Burma where most of these insurgent groups operated and where many of Burma's most exportable resources lie." Several militias funded their campaigns through black market trades in drugs and natural resources; leaders in the Tatmadaw showed a willingness to suspend operations against these groups in return for a cut of these trades. The ceasefire with the UWSP, for example, was based on the Tatmadaw receiving a share of the group's drug-trafficking revenues (Jonsson, Brennan, and O’Hara 2016).

Given the Tatmadaw's grip on political and economic power, it was a surprise then for many when democratic reforms were initiated in 2011. There is extensive debate on why the Tatmadaw would agree to transition; these arguments range from desires to re-engage the west, to Chinese pressure, to worries of future uprisings (see Zin and Joseph 2012; Jones 2014, for summaries). Regardless of the precise substantive reasoning, what can be said is the military regime initiated reforms from a position of strength (Callahan 2012; Slater 2014). In 2008, a new constitution was adopted that ensured the military's continued control under the new "democratic" system. The constitution allows the Tatmadaw to retain 25 percent of seats in the Hluttaw (effectively, a constitutional veto); have exclusive appointment of one of the two vice presidents; operate military affairs without civilian oversight; and appoint the powerful defense, home affairs, and border affairs ministers (Kingsbury 2014; Lintner 2015). The constitution also created of the National Defense and Security Council (NDSC). Comprised of 11 members, six of which are appointed by the army commander, the NDSC is Myanmar's supreme arbitrating body (Kingsbury 2014). The NDSC has the capacity to declare 
a state of emergency, under which it may then dissolve the Hluttaw and take over all legislative, executive and judicial powers. As is clear, the Tatmadaw was able to negotiate a withdrawal that maintained significant political power.

That said, the military's hold on some of its most valuable economic rents has been challenged in the post-transition period. New tax policies enacted after 2011 have subjected military-owned enterprises to taxation for the first time in Myanmar's history, and the UMEHL and MEC have lost their lucrative monopolies on cars, cooking oil, cigarettes and beer (Economist 2013). As recently as 2014, the military-owned mobile operator MPT had an uncontested 100\% market share, which fell to $46 \%$ as of 2016 in the face of competition from two international providers. Recent investigative reporting by national media has increasingly put military-owned enterprises under the microscope for tax evasion and questionable business practices (Sone 2013). With earnings from the formal economy under increasing pressure and public scrutiny, illicit revenues from the jade sector have taken on an even greater importance to the Tatmadaw in the post-transition period.

\subsection{The Jade Trade in Myanmar}

As the ceasefire agreement with the UWSP suggests, the Tatmadaw has deep ties to Myanmar's illicit exports, especially jade. Kachin State in north-central Myanmar has the highest quality jade in the world, with the largest mines located between the Uru and Chindwin rivers (Hughes et al. 2000). Major jade-mining areas include Tawmaw, Hweka and Mamon, with Hpakant being the center of the jade-mining district (Chang 2006). Large-scale excavation in this region dates back to the second half of the 18th Century (Nyunt 1995).

After the coup in 1962, the Revolutionary Council (RC) nationalized the Burmese economy and made all private transactions of gemstones and natural resources illegal (Chang 2006). Consequently, the 1960s and 1970s marked the rise of illicit exports: "the consumption demands of Burmese society were met by the black market linked to the underground border trade. Natural resources and raw materials such as rice, teak, cattle, antiques, hides, ivory, opium and jade stones were smuggled out to neighboring countries from areas controlled by rebel groups, and in return 
daily consumer items and weaponry were smuggled into Burma” (Chang 2004, 48).

In 1995, the SLORC passed the Myanmar Gemstone law, allowing citizens to trade jade (Hughes et al. 2000). This law imposes strict regulations on jade production: the Ministry of Mines's gemstone division allocates jade concessions; legal sales must occur at the annual, government-organized emporium; and stones are taxed twenty percent at the mine site and another ten percent when sold (Global Witness 2015, 34-5).

In practice, these regulations are selectively enforced or simply flouted to the benefit of the country's military elite. Jade holdings have been, and continue to be, concentrated among companies with military connections: "the licensing process is weighted heavily in favour of a powerful elite connected or allied to the [then] ruling Union Solidarity and Development Party [the political party formed by the junta] and the military" (Global Witness 2015, 29). When, prior to transition, the US imposed sanctions on Myanmar, it was estimated that "the military earned in excess of 300 million" in 2006 from the gem trade (110th US Congress 2008). We reviewed the set of entities sanctioned by the US Treasury Department following the 2008 JADE Act and found that more than 90 percent could be linked to military commanders (see Section A.3). Little has changed since 2011, Global Witness estimates that military families (often commanders' wives serve as owners of record) and their companies made over a billion dollars from their official jade sales in 2013 and 2014. And the latter figure represents a lower bound, as most jade is smuggled out of the country, avoiding the heavily taxed emporiums. Global Witness $(2015,36)$ reports estimates that upwards of 50 to 80 percent of jade is smuggled into China; Dapice and Nguyen (2013) estimate that less than ten percent of total jade sales in 2011 were taxed by the central government.

Military elite not only have large stakes in major mining operations, they also run a lucrative racket in Kachin State. Global Witness $(2015,89)$ reports that military officers demand twenty percent of the value of any stone found by smaller scale, artisanal miners. Moreover, the Tatmadaw receives payments from concessionaires, who both pay for soldiers to guard their compounds and distribute bribes to clear any roadblocks along their smuggling routes. 
Proceeds from illegal jade exports not only benefit military elites and their cronies, but have also provided an important source of income for the Kachin Independence Army (KIA). The KIA, the armed wing of the Kachin Independence Organization (KIO), has consistently been one of the largest and most active insurgent groups in Myanmar since its formation in 1961. According to the Myanmar Peace Monitor, the group boasts membership of close to 10,000 troops and occupies territory in Kachin State as well as in northern Shan State. Funding for the KIA also comes from a variety of other sources; as it has lost control of jade-mining areas, it has relied more heavily on illegal logging and timber sales.

\section{Conflict as a Strategy for Retaining Control}

Jade mining provides the Tatmadaw with an enormous stream of rents, which they do not want to see diverted to a civilian government. Global Witness $(2015,38)$ concludes: "because the big companies are, in many cases, owned or aligned with entrenched military and [USDP] party figures, they have everything to lose if the rules of the game change following the November 2015 elections or in the event of an equitable peace agreement between [the government in] Nay Pyi Taw and the KIA/KIO."

Given what is at stake, how can the military stymie reforms that threaten its rents? Drawing on past work regarding the military's response to political transitions, we argue that the military strategically uses violence to deter any civilian government from directly administering valuable territory, leaving control in the military's hands. ${ }^{7}$

First, consider the period prior to democratization, when there is no civilian government to challenge the military. In this setting, the first-best outcome is for the military and any local rebel

\footnotetext{
${ }^{7}$ For this to be an effective strategy, there must be a plausible adversary in the territory that the military hopes to retain. The civilian authority is unlikely to be deterred by war games that lack a credible opponent.
} 
group to split the proceeds from economic activity (in this case, jade mining and smuggling). ${ }^{8}$

This is Kachin State between the mid-1990's and 2010. During this period, the Tatmadaw and KIA/KIO forged a ceasefire that did not resolve political grievances, but did establish a mutually beneficial bargain. Reports from this period suggest that the military and KIA/KIO - while ostensibly foes - colluded to sustain their mutual interest in the jade trade. Observers note that "the Tatmadaw and KIA maintain close contact in Hpakant [the largest jade-mining area] to agree on how much tax each will receive from significant jade finds" (qtd. in Global Witness 2015, 90). The Global Witness report continues, "the Tatmadaw Tactical Commander and KIA Battalion 6 use the same jade brokers to levy payments from small-scale miners and to maintain communications, thereby reducing the scope for misunderstandings that might lead to armed confrontation." The military and local rebels actually endeavor to prevent informational asymmetries that could derail their lucrative and largely peaceful bargain.

Second, political reforms permit the possibility of greater civilian control; a civilian administration might develop an interest in administering lucrative sectors of the economy. And yet, civilians cannot effectively collect revenues in an active war zone. The military, thus, has an incentive to initiate violence in valuable territories to hamper the development of a competing authority (Keen 2014). ${ }^{9}$

We argue that this is Myanmar in the aftermath of its political transition (see Lintner 2013b, for skepticism regarding the depth of reform). The resumption of conflict in jade-mining areas is a strategy used by the Tatmadaw to deter civilian control. "The notion of Kachin State being un-

${ }^{8}$ Well-known results from bargaining theory suggest that in a game with complete information, these parties should immediately and amicably agree on how to split the pie (Fearon 1995).

${ }^{9}$ To validate this claim, we examine data on the issuance of national identification cards and initiation of foreign aid projects across townships. We find that the proportion of the population with national identification cards and the number of aid projects are lower in areas with active conflict, suggesting (perhaps unsurprisingly) that violence limits access. 
governable," Global Witness $(2015,29)$ argues, "allows this [military and USDP] elite to perpetuate the idea that applying transparency reforms such as EITI to the jade business is not possible. This sustains the secretive, abusive and highly lucrative status quo." While we might naively assume that the military has an interest in peace and order, in this case, it retains its lucrative nondemocratic prerogatives in the jade trade by ensuring that jade-mining areas are too dangerous to be managed by civilians. Barany (2016) observes that the Tatmadaw employed a variant of this strategy to sustain its fifty years of rule: "Owing to military elites' economic stakes - involvement in the illegal trade in drugs, gems, lumber, etc. - they had a vested interest in the continuation of hostilities. Furthermore, the generals could use the on-going conflict to further justify their claim to their rule."

This argument assumes that the civilian government is a real threat to the Tatmadaw's control of jade-mining areas. Without denying the Tatmadaw's continued authority in Myanmar, their control is no longer absolute. The Tatmadaw high command no longer has the same powers over policy that it did before the transition: "with the 2011 government having created a legal space for politics, the [Tatmadaw] no longer claims an unchallengeable monopoly of all public authority" (Callahan 2012, 127). This extends to the jade sector. Shortly after 2011, the Thein Sein government announced its intention to tax previously sheltered UMEHL and MEC, military holding companies with substantial interests in the jade sector (Sone 2013). At the same time, the then-ascendant, now-ruling National League of Democracy (led by Aung San Suu Kyi) included strong language in its platform about increasing government revenues from the jade sector and cracking down on smuggling (Zaw 2015). ${ }^{10}$ A more recent announcement by the NLD government that they plan to overhaul the jade-mining sector represents a public warning shot. "Freezing licenses," according to the Secretary General of the Kachin Development Networking Group, "is a critical first step towards wresting control from the elites who have plundered the country's jade riches for so many years" (Global Witness 2016).

${ }^{10}$ Even prior to the 2015 elections, reports suggest that senior leadership in the Tatmadaw worried about how the KIA/KIO and its calls for federalism might become an "obstacle to business interests among the ruling elite" (Transnational Institute 2013, 5). 
These actions are not simply political theater; the assertiveness of the civilian government is felt in mining areas. Interviews with jade miners indicate that the scramble for resources has intensified:

“They try to mine as much as possible as fast as possible. Mom [Daw Aung San Suu Kyi]

is coming to check up, so the kids grab as many cookies as they can from the cookie jar while they can." (qtd. in Global Witness 2017)

And the military has allegedly hampered increased civilian oversight by timing attacks to disrupt visits by ministers or international observers, using conflict as an excuse to defer reforms (Global Witness 2017). As of 2017, the military's strategy appears to be working.

Our argument has two observable implications. First, we expect conflict to increase dramatically after political transition. Second, this increase in conflict should occur primarily in jademining areas, where returns to deterring civilian control are high.

In other settings, the civilian government might see through this charade and disregard violence as a bargaining tactic cynically deployed by the military. ${ }^{11}$ Yet, in an area still occupied by a historically rebellious ethnic army, the civilian government cannot easily discern whether violence reflects renewed separatist activity or military provocation. As such, the military can exploit unrest in this region - even of its own making - to convince an uncertain civilian government to cede authority to the generals in administering lucrative and "disputed" territory. This suggests a scope condition for our argument: prior contestation in a territory bolsters the military's claim that their continued presence is necessary for legitimate defensive purposes. ${ }^{12}$

Our theory suggests two other scope conditions that enable the military to strategically deploy

\footnotetext{
${ }^{11}$ The violence in jade-mining areas is not between the military and civilian government and, thus, does not reflect their failure to reach a bargain. Rather, we argue that the military uses violence in these peripheral areas to bolster its bargaining position vis-a-vis the ascendant civilian administration.

${ }^{12}$ This is not a particularly restrictive condition given the limits of state control in border areas throughout much of Africa and Asia (Herbst 2000; Scott 2009).
} 
violence to retain control of a valuable reserved domain. First, valuable assets, such as natural resources, must fall within the territory under a plausible, pre-existing threat. ${ }^{13}$ This is often the case, as separatists seek to wrest control and gain autonomy over lucrative regions. And second, the outgoing autocratic regime needs to influence military decision-making, for example, by occupying or exercising influence over positions of authority.

These three scope conditions encompass many recent and contemporary cases. Assembling data on autocratic regimes, conflict, and mining, we roughly classify the set of countries that meet our scope conditions..$^{14}$ First, we map all sub-provincial units - equivalent to counties in the US - using the Database of Global Administrative Areas (GADM). Second, we spatially merge in (1) point data on over 300,000 mineral deposits from the US Geological Survey's Mineral Resources Data System (MRDS), which is current as of 2011; and (2) data on armed conflict from the UCDP GED database, which covers 1989 to the present (described below). This allows us to identify all autocracies containing districts with both natural resources and past conflict. ${ }^{15}$ The resulting list (see Table A.13) includes thirty countries, including Angola, Eritrea, and Ethiopia (all identified in our reading of the secondary literature), as well as our case, Myanmar. This exercise and secondary literature on other cases suggest that the dynamic we uncover is not unique to Myanmar.

\footnotetext{
${ }^{13}$ These assets must be valuable from the perspective of the outgoing regime.

${ }^{14}$ The latter two scope conditions may be more often satisfied where long-standing military regimes have, during their long tenure, conquered core industries. In these settings, the outgoing regime is likely to have reserved domains it is reluctant to relinquish and will, absent a purge of the military command, exercise continued control over military decision-making.

${ }^{15}$ We operationalize autocracy as those countries with average Polity IV scores less than or equal to zero between 1989 and 2011.
} 


\section{Data}

We employ conflict data from the Uppsala Conflict Data Program Georeferenced Event Dataset (UCDP GED). ${ }^{16}$ The data are event-based, and we only retain events that can be geo-coded to townships or more specific locations within townships. A conflict event is defined as "an incident where armed force was used by an organized actor against another organized actor, or civilians, resulting in at least 1 direct death at a specific location and a specific date" (Croicu and Sundberg 2015, 2). ${ }^{17}$ Information about conflicts are based on global newswire reporting and local news, as well as secondary sources such as local media and NGO field reports. The dataset codes each violent event by date, location and groups involved.

A limitation of news-based incident reports, such as UCDP, is that coders must rely on local reports, including from combatants, to determine the initiators and targets of attacks and characterize them as civilian, government, or rebel. After reviewing the stories behind the UCDP incident reports, we find that UCDP "state-based incidents" are more often reported as initiated by both sides (though predominantly by the Tatmadaw). For "one-sided" events, reportage consistently claims

${ }^{16}$ For this analysis we use version 4.0 which covers conflict events from 1989 to 2014 . We also use the UCDP's API to acquire events from 2015. The code book is available at http://www . pcr.uu . se/ research/ucdp/datasets/.

${ }^{17}$ Lower-level social conflicts, which are not included in the UCDP data (e.g., protests), may have also changed with the 2011 transition. We do not have the data to assess these trends, though our theory and reading of the secondary literature do not suggest a concentrated increase in jade-mining areas. (We discuss the violent protests around the Myitsone Dam in Section 7.4.) We focus, however, on UCDP conflicts as these directly relate to our argument: if the Tatmadaw, the most organized armed actor in Myanmar, deployed violence (whether defensive or offensive) against civilians or other armed groups this would be included as a UCDP event. The focus on events involving a fatality restricts attention on serious flare ups, rather the tensions and disputes endemic to ungoverned border regions. 
that conflict was initiated by the government, though it is typically contested whether their targets are civilians or rebels. As a example, the following is a one-sided event from the UCDP data: ${ }^{18}$ January 2013. "Burmese military admits airstrikes against Kachin” — "Burma’s military acknowledged launching airstrikes against ethnic Kachin rebels in the north and said it captured a hilltop post...The military announcement highlights a seeming disconnect between the government and the military, which retains much power behind the scenes. An order late last year by Thein Sein to halt offensive operations against the Kachin was not honored in practice."

We aggregate the data to the township-year level and use the logged total number of violent incidents as the primary dependent variable. ${ }^{19}$ Figure 1 shows a map of logged conflict events at the district level (the administrative division above townships). ${ }^{20}$

Mining data is gathered from the GEMDATA dataset, which provides coordinates for gemstone deposits throughout the world (Lujala 2009). The dataset contains information on gemstone sites, including jade, in 61 countries (Floter, Lujala, and Rod 2005). Data were collected in 2004, prior to the transition and resumption of conflict, and include longitude and latitude of gemstone sites, as well as the types of gems being produced. For our empirical analysis we record the total number of jade producing sites within a township. ${ }^{21}$ Figure 1 includes a map of jade mining by district.

${ }^{18}$ We include additional event descriptions in Section A.14.

${ }^{19}$ More precisely, we use the common transformation $\log (y+1)$ to avoid dropping townships with zero events. Our results do not hinge on this transformation and the assumed functional form: in sections A.8 and A.9 we show that our results are robust to employing the inverse hyperbolic sine transformation or just using the raw counts, respectively.

${ }^{20}$ Summary statistics for key variables are shown in Table A.1.

${ }^{21}$ Timber, commercial agriculture, or strategic locations like ports do not meet our scope conditions as they are small in value, not deeply linked to the military, or do not coincide geographically with areas of plausible instability. Due to the illegality of drug production and trafficking, the civilian 
Figure 1: Conflict Incidence from 2006-2015 and Jade Mining by District Note: Subsequent analysis is at the township-level.

$\log (\mathrm{UCDP}$ Events + 1) 011233

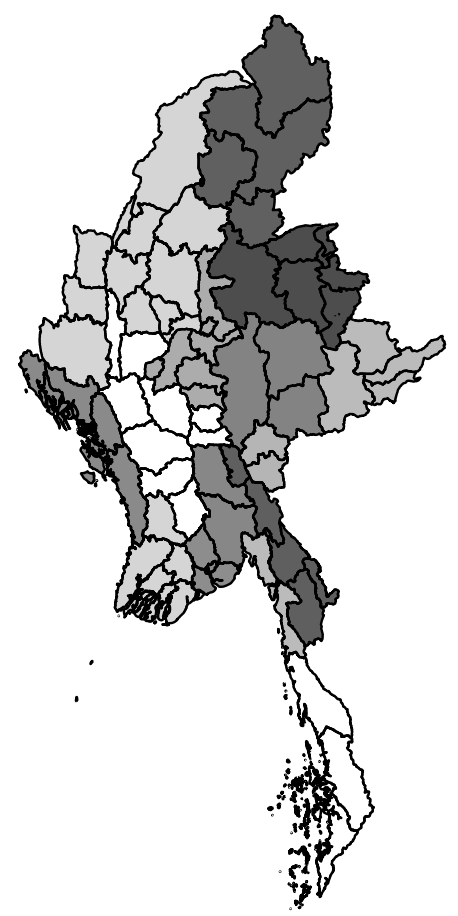

Jade Mines $\begin{array}{llllll}0 & 1 & 2 & 3 & 4 & 5\end{array}$

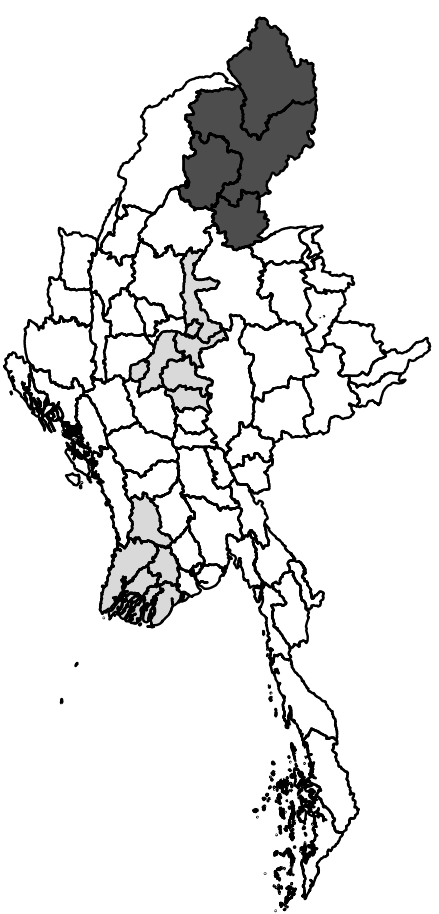

Notes: This figure shows conflict intensity and jade mining in Myanmar districts. Conflict intensity is measured in logged number of conflict events (plus one). Jade mines represents the total number of jade mines in 2004. The shapefile comes from by Myanmar Information Management Unit (MIMU); conflict data, from UCDP GED; mining data, from GEMDATA.

For methodological reasons, we prefer a pre-transition measure of mine locations. The GEMDATA from 2004 allows us to avoid concerns that mining activity changes in response to renewed conflict in Kachin, a clear instance of post-treatment bias (Montgomery, Nyhan, and Torres 2018). Readers may, however, be concerned about measurement error. First, we reviewed the available data

government does not have the same financial interest in wresting control of this sector during the transition. 
on jade concessions since 2004 in Myanmar, finding no evidence of major changes in the extent of jade mining at the township-level. Second, classical measurement error would only serve to attenuate our estimates. Finally, we employ a binary measure of mining activity in Table A.11 to alleviate concerns about our data measuring the precise number of active mines, as opposed to the presence of any mining activity. Though less precise - the binary measure throws away information — our results are qualitatively similar.

\section{Empirical Strategy}

We employ a difference-in-differences design, estimating differential changes in conflict before and after the transition for townships that do and do not host jade mines. ${ }^{22}$ More technically, let $D_{i t}$ be the product of the number of mines in a township and a dummy variable for the post-transition period $\left(D_{i t}=\#\right.$ Mines $_{i} \times \mathbb{1}($ Year $\left.\geq 2011)\right)$. We estimate:

$$
y_{i t}=\alpha_{i}+\beta_{t}+\gamma D_{i t}+\varepsilon_{i t}
$$

where $i$ indexes townships; $t$, years. Note that the direct effects of the number of mines or the posttransition period are absorbed by the township and year fixed effects ( $\alpha_{i}$ and $\beta_{t}$, respectively). In robustness checks, we include township-specific linear time-trends ( $\tau_{i}$ Year) to absorb any secular (linear) trends in conflict incidence within each township. In equation $1, \gamma$ represents the posttransition increase in conflict associated with each additional jade mine, after differencing out the change in conflict observed in other parts of Myanmar. This approach exploits sub-national variation in conflict trends; any explanation that causes a nationwide shift in hostilities or generates time-invariant level differences in conflict cannot explain our results. We cluster our standard errors on township for all models.

${ }^{22}$ As we only have jade prices starting in 2006, we restrict attention to 2006 and beyond; including more data prior to the transition does not affect our findings. 
Our design hinges on the parallel trends assumption - that areas with and without mines would have followed the same trend in conflict in the absence of any political reforms. While untestable, we take several steps to shore up its credibility. First, we show that, prior to the transition, both mining and non-mining townships followed similar trends regarding conflict incidence. This is both apparent in Figure 2 and also verified through a series of placebo tests. In Figure A.1, we estimate equation 1 using data from the pre-transition period (1995-2010), and coding $D_{i t}$ using years prior to the actual transition. The "placebo" (i.e., fake) transitions consistently generate null findings, indicating that mining and non-mining areas do not follow divergent trends prior to 2011.

Second, we pre-process our data, re-weighting our non-mining observations to ensure balance across pre-treatment measures. More specifically, we employ entropy balancing using the following pre-treatment variables: median altitude, average nighttime luminosity between 1995-2000 and 2000-2005, and the sum of different types of conflict between 1995-2000 and 2000-2005 (logged) (Hainmueller 2011). ${ }^{23}$ By weighting to generate balance on elevation and pre-treatment measures of development and conflict, we hope to generate a control sample that better approximates the counterfactual trend that mining areas would have followed. To implement this routine, we dichotomize townships into mining or non-mining, dispensing with information about the number of mines.

${ }^{23}$ Data on altitude comes from Hijmans et al. (2005), who provide interpolated agro-climatic variables at a 1-km spatial resolution (i.e., measures of altitude, precipitation, or temperature for every square kilometer of the globe). We aggregate these measures to the township, taking the median elevation given the skew of measure. We use information on nighttime lights collected by the Defense Meteorological Satellite Program's Operational Linescan System (DMS-OLS). This data also comes at a $1-\mathrm{km}$ resolution; we take the average across cells in each township year. A number of studies have demonstrated a robust positive correlation between nighttime luminosity and other indicators of development (Weidmann and Shutte 2016; Chen and Nordhaus 2011; Doll, Muller, and Morley 2006). 


\section{Results}

Our main results are apparent in the raw data. Figure 2 plots the average number of conflicts in jade mining (black) and other townships (light gray). While there is effectively no conflict between 2006 and 2010, we see a big jump in violence after 2010 (gray area) that is limited to jade-mining areas. This figure foreshadows the regression results presented below: we see a sharp and differential increase in violence in jade-mining areas after the transition. ${ }^{24}$ Moreover, while prices increase almost monotonically over the period (see Figure A.3), we do not find a positive relationship between commodity price changes and conflict after accounting for the effect of the transition.

In substantive terms, from 2006-2010, townships without jade mining averaged just over one battle death according to UCDP; jade-mining areas saw zero battle deaths. This contrasts sharply with the period from 2011-2015, in which jade-mining townships averaged over 41 battle deaths, while other townships maintained a much lower average of just over 3 fatalities. These figures do not capture the displacement and collateral damage associated with conflicts.

The moderate increase in violence reflects the incentives for the Tatmadaw. They are not inclined to wage a full on war; instead, we should expect the level of conflict to be only enough to dissuade civilian authorities from exerting control, while allowing exploitation of resources to continue. Violence we uncover - an average of 41 battle deaths (3-4 fatalities per month) in jade townships versus 3 in non-jade mining - seems consistent with maintaining a low-intensity fight that supports a narrative of insecurity.

We start by estimating the difference-in-differences specified in equation 1 . Whether we use all events, state-based conflicts, or one-sided conflicts, we find consistent evidence that violence — and specifically violence perpetrated by the Tatmadaw - increases more markedly in jade townships

\footnotetext{
${ }^{24}$ See also Figure A.2, which shows density plots of conflict counts before and after the transition for mining and non-mining townships. While these distributions are identical prior to 2011, the distribution shifts dramatically to the right in mining areas after the transition.
} 
Figure 2: Jade Mining and Conflict, 2006-2015

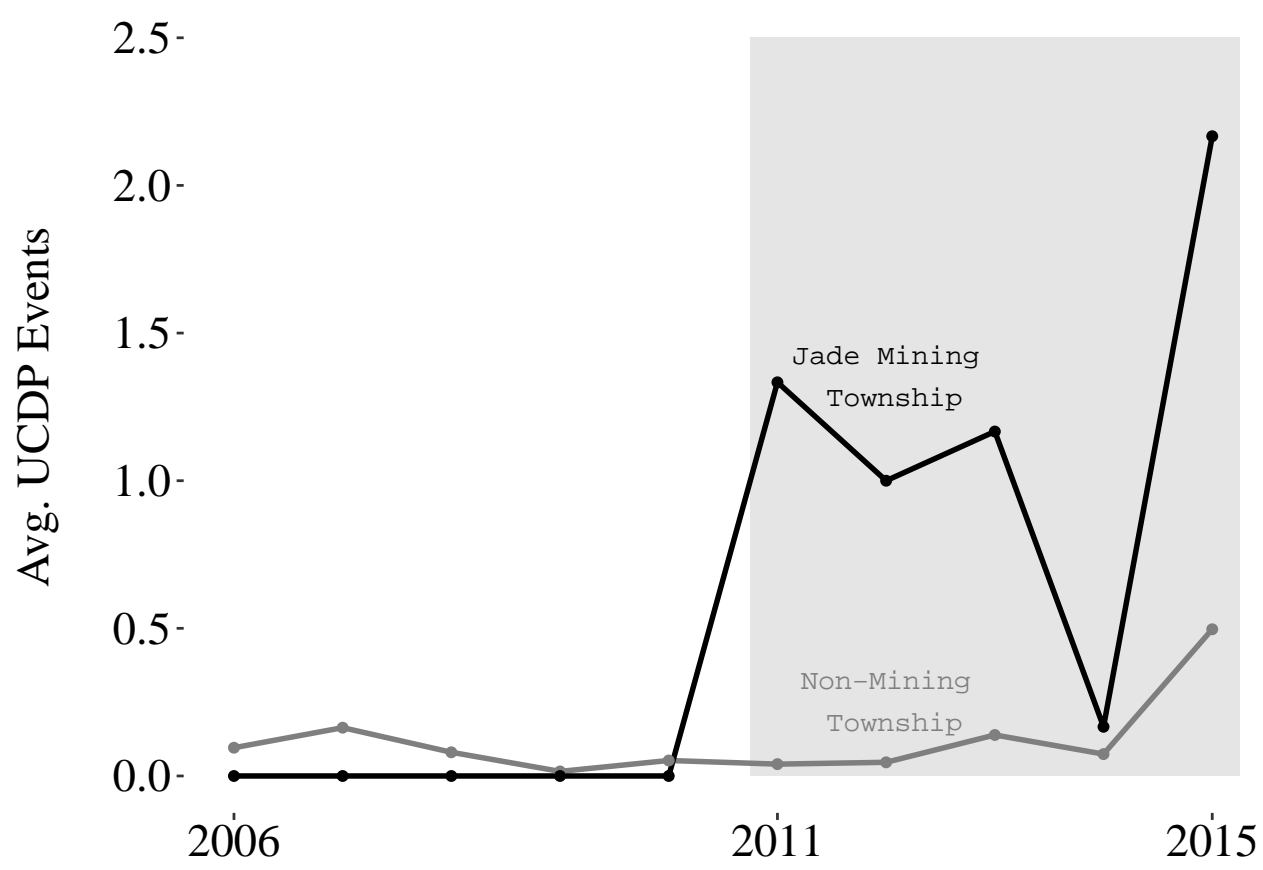

Notes: This figure shows the average number of conflicts in townships with jade mining (black) and in townships with no jade mining (light gray). The shaded gray area indicates the post-transition period. Conflict data comes from UCDP GED; mining data, from GEMDATA.

following the political transition in late $2010 .^{25}$ The coefficient in Table 1 , model 1 suggests that the transition led to a roughly 27 percent increase in conflict per jade mine. This result is robust to dropping any of the jade-mining townships from the sample. In Sections A.8 and A.9, we use the inverse hyperbolic sine transformation of our dependent variable recommended by Burbidge,

${ }^{25} \mathrm{~A}$ state-based event is an incident where armed force was used by an organized actor against another organized actor, of which at least one is the government (party controlling the capital) of a state. A one-sided government event is an incident where armed force was used by the government of $a$ state against civilians. Finally, a non-state event is an incident where armed force was used by an organized actor against another organized actor, neither of which is the government of a state. In all cases, the conflict must result in at least one direct death at a specific location and on a specific date (Croicu and Sundberg 2015). 
Magee, and Robb (1988) and the raw counts of conflict, respectively; our results are unchanged.

Models 2 and 3 confirm on-the-ground assessments that a Tatmadaw offensive drove this increase in violence (e.g., Naing 2012): nearly all conflict events involve the Tatmadaw, and we observe a meaningful increase in government forces attacking civilians. No reports indicate that conflicts pitted Tatmadaw regiments against each other (Gravers and Ytzen 2014, 266).

Table 1: Effect of Political Transition on Violence in Jade Townships

\begin{tabular}{lccc}
\hline \hline & \multicolumn{3}{c}{ Dependent variable: } \\
\cline { 2 - 4 } & $\log ($ Total +1$)$ & $\log ($ State-Based + 1) & $\log ($ One-sided + 1) \\
& $(1)$ & $(2)$ & $(3)$ \\
\hline \# Mines $\times$ Post-2010 $\left(D_{i t}\right)$ & $0.267^{*}$ & $0.221^{*}$ & $0.114^{*}$ \\
& $(0.032)$ & $(0.033)$ & $(0.015)$ \\
& & & 330 \\
Township FEs & 330 & 330 & 10 \\
Year FEs & 10 & 10 & 3,300 \\
Observations & 3,300 & 3,300 & \\
\hline \hline
\end{tabular}

Note: $\quad$ Robust SEs clustered on township; ${ }^{\dagger} p<0.1,{ }^{*} p<0.05$

Notes: OLS models using the specification from equation 1. Standard errors clustered at the township level are shown in parentheses. The dependent variable is the log of total events, state-based events, and one-sided government events (see Section 4).

To rule out the possibility that mining townships are simply increasing in conflict over the whole period, we include township-specific linear time-trends. Our coefficients increase slightly in magnitude (see Table A.3).

We then augment our difference-in-differences with a pre-processing routine to generate balance along pre-treatment measures of elevation, economic development, and conflict. Table A.4 first shows that this technique effectively generates balance; by re-weighting non-mining townships we can generate a control sample that is statistically indistinguishable from mining areas in terms of elevation or past economic development or conflict. We estimate equation 1 using our re-weighted sample (taking the weights as fixed), and our findings do not change (see Table A.5). We find pos- 
itive and significant effects on the incidence of all or state-based conflicts; the effect on one-sided violence remains positive but is less precisely estimated $(p=0.17)$.

Finally, our placebo tests reassure us that differential pre-trends do not account for our findings. Using data prior to 2011, we recode $D_{i t}$ using years prior to the actual political transition. If jademining areas were experiencing an uptick in violence in advance of political reforms, these placebo estimates would be positive. Yet, we find consistent null effects that stand in sharp contrast to our actual estimate (see Figure A.1).

\section{Alternative Explanations for Violence}

\subsection{Reaction to a Deteriorating Security Situation}

We argue that the increase in violence after 2010 reflects an offensive by the military in Kachin State. This is apparent in the composition of conflict events: nearly all events involve the Tatmadaw; moreover, government-perpetrated attacks against civilians (and not involving rebels) increase. This is also consistent with contemporary accounts of the fighting. Human Rights Watch, for example, blames the Tatmadaw for the resumption of violence in June 2011: "The Burmese army first attacked a strategic KIA post... The army subsequently launched a major offensive and moved in hundreds of troops to areas formerly controlled by the KIA" (Human Rights Watch 2011). In fact, Lintner (2013a) argues that the Tatmadaw had well-laid plans to attack the KIA. Summarizing military sources, he reports that "there was little doubt at the time that the [Tatmadaw] intended to break the ceasefire it had maintained with the KIA since February 1994."26

However, there could be other changes occurring around the transition that affect the security situation in mining areas. If true, the military could be reacting to a deteriorating security situation in mining townships, rather than initiating violence.

To evaluate this possibility, we look for differential changes in non-state conflicts (i.e., in this

${ }^{26}$ The centralized planning of the offensive suggests that the violence was not the result of predation by local commanders. 
context, conflict between ethnic armed organizations) after the transition in mining and non-mining townships. We find no increase in conflicts among non-state actors in mining areas before and after the transition (see Table A.10). ${ }^{27}$ With and without township-specific trends, our estimates are precisely estimated zeros. This both points to our preferred mechanism - a proactive military strategy - and alleviates concerns about unobservables contributing to increased instability in mining areas.

Both news accounts and the data suggest that the upsurge in violence in mining areas is the result of a destabilizing military offensive, rather than a defensive response by the Tatmadaw (e.g., Naing 2012). Global Witness $(2015,89)$ offers a stark assessment of the Tatmadaw's objectives in the region, claiming that "the Tatmadaw's main priority in Hpakant is milking money from the jade business and this imperative frequently trumps its designated function of fighting the KIA."

\subsection{Shift in Military Strategy and Relations with Armed Groups}

Our primary findings cast doubt on a country-wide shift in the strategy of the military or ethnic armed organizations. If, in the wake of the transition, the military or armed groups simply became more bellicose - seizing, perhaps, on a perceived moment of strength - we would expect an uptick in violence across Myanmar's contested areas, a classification that covers large swaths of the periphery, including parts of Chin, Mon, Kachin, Kayin, and Shan states. ${ }^{28}$ Yet, as is apparent in Figure 2, non-mining townships largely avoided renewed conflicts. And looking at equation 1, any such secular trend in conflict would be absorbed by our year fixed effects and, thus, could not explain our results.

Using recently compiled data from the Asia Foundation's Township Development Indicators,

${ }^{27}$ In addition to the KIA/KIO, several other militias operate in Kachin, including the Arakan Army, New Democratic Army Kachin, Kachin Defense Army, Kachin National Organization, and All Burma Students Democratic Front.

${ }^{28}$ Furthermore, it is difficult to rationalize rebel groups lashing out as the military's perceived power declines. Per Fearon (1995), it is the waning side that has an incentive to preemptively attack. 
we can go further, identifying the 57 townships covered by ceasefires signed by government and armed groups in or before 2011. We then look at whether violence increased more dramatically in these previously contested areas following the political transition (see Table A.6). We do not find a resurgence of violence in these townships after 2011, suggesting that the Tatmadaw battles in jademining areas were not part of a broader offensive against - or mobilization among - insurgent groups.

We also use data on the location of military headquarters - specifically, the locations of Regional Military Commands, Regional Operation Commands, and Light Infantry Divisions - to ensure that these do not fall in jade-mining townships. According to data compiled by the Asia Foundation, the Regional Military Command in Kachin State is located in Myitkyina along with the 99th Light Infantry Division; the Regional Operation Command is headquartered in Tanai. ${ }^{29}$ Critically, neither of these townships includes jade mines according to the GEMDATA. Our results cannot, thus, be attributed to increased violence near bases and the coincidental co-location of military headquarters and mines.

\subsection{Commodity Price Changes}

A number of studies in political economy find a positive relationship between commodity prices and armed conflict in mining areas (e.g., Collier and Hoeffler 2002; Dube and Vargas 2013). Dal Bó and Dal Bó (2011) offer a model to rationalize these findings, arguing that rising commodity prices inflate insurgents' ranks with individuals keen to predate on increasingly lucrative mining operations.

Employing data on the price of (or international demand for) jade, we also look at whether conflict in mining areas increases with the price of jade. Information on jade prices comes from Global Witness (2015), which compiled data on sales at every official Myanmar Gems Emporium

\footnotetext{
${ }^{29}$ While this data was compiled after the transition, the headquarters of the Regional Military Command and Regional Operation Command were established prior to 2011.
} 
between 2005 and 2014, as well as official revenues from mine site taxes and production data. We calculate the average jade price by dividing the total value of sales by the total volume sold. We note that sales prices at the emporiums are likely downwardly biased, as the most lucrative jade is often smuggled into China. If this downward bias is consistent over time, then it will not confound our empirical strategy which exploits changes in price.

We start by estimating a naive model that ignores the political transition that occurs in 2011:

$$
y_{i t}=\alpha_{i}+\beta_{t}+\psi\left[\mathbb{1}(\text { Mine }>0)_{i} \times \log \left(\text { Price }_{t-1}\right)\right]+\epsilon_{i t}
$$

where, again, $\alpha_{i}$ and $\beta_{t}$ are township and year fixed effects. The direct effects of the number of mines or price are absorbed by the unit and time fixed effects. In this equation, $\psi$ captures the differential effect of jade prices on violence in townships that do and do not have jade mining. ${ }^{30}$

The identifying assumption for this naive model is that the areas that do and do not mine jade would have experienced parallel trends in conflict had prices remained flat. However, our theory

${ }^{30}$ As Myanmar is one of the top producers of jade, one might be concerned that violence reduces supply and boosts jade prices - a clear case of reverse causality. We address this issue in two ways. First, we lag price by a year, ruling out bias generated the relationship between contemporaneous conflict and prices. Second, we exploit the fact that nearly all jade produced in Myanmar is exported to China for use in expensive jewelry and other luxury goods. Shor (2013) notes that with China's rising wealth comes rising demand, and therefore, prices for jade. Given the importance of Chinese demand for jade prices, we substitute jade prices in models 2 and 3 with Chinese luxury sales specifically, high-end car sales - to isolate exogenous variation in prices. These data on Chinese luxury demand come from the National Bureau of Statistics of China and cover the period from 1998 to 2015 (http://data.stats.gov.cn/english/index.htm). The implied exclusion restriction is that Chinese luxury demand does not affect conflict in Myanmar except through its effects on jade prices; we find no qualitative evidence questioning this assumption. 
suggests that this is an imprudent assumption. We argue that jade-mining areas saw an abrupt increase in violence starting in 2011 due to the political transition. To demonstrate that the political transition - and not price changes - led to increased violence in jade-mining townships, we take two approaches. First, we separately estimate equation (2) using the periods before and after the transition.

Second, we nest equations (1) and (2) and estimate:

$$
y_{i t}=\alpha_{i}+\beta_{t}+\Gamma J_{i t}+\Psi\left[\mathbb{1}(\text { Mine }>0)_{i} \times \log \left(\text { Price }_{t-1}\right)\right]+\eta\left[J_{i t} \times \log \left(\text { Price }_{t-1}\right)\right]+\epsilon_{i t}
$$

where $J_{i t}$ is an indicator for jade-mining areas after the transition. In this specification, $\Psi$ and $(\Psi+\eta)$ represent the relationship between changes in price and conflict in jade-mining areas before and after the political transition, respectively. To capture the post-transition increase in conflict in jade-mining townships, we sum $\Gamma+\eta \times$ Avg. $\log$ (Price), where the average price is calculated using the post-transition sample. We expect a sharp increase in conflict after the political transition; yet, prior to 2011, we do not expect to see any relationship between prices and conflict given the bargain between the Tatmadaw and KIA/KIO (i.e., $\Psi$ and $\Psi+\eta$ should be close to zero).

We find that a naive specification, which ignores Myanmar's political transition, suggests that conflict increases with jade prices (see Table 2, model 1). However, this is simply because jade prices increase nearly monotonically from 2006 to 2014, and violence in jade-mining areas is concentrated at the end of the period, in the wake of the transition. In models 2 and 3 we look separately at the relationship between prices and conflict in jade-mining areas before or after the transition, we find no evidence that higher prices exacerbate armed conflict in mining areas in either period. ${ }^{31}$ Our estimates of $\psi$ from equation 2 in models 2 and 3 are substantively small and, for the period after the transition, indistinguishable from zero. Looking at the final, nested model in Table 2, even

\footnotetext{
${ }^{31}$ While the scales change, our findings are not affected by substituting Chinese luxury demand for jade prices (see Table A.12).
} 
Table 2: Effect of Political Transition and Prices on Conflict in Jade Mining Areas

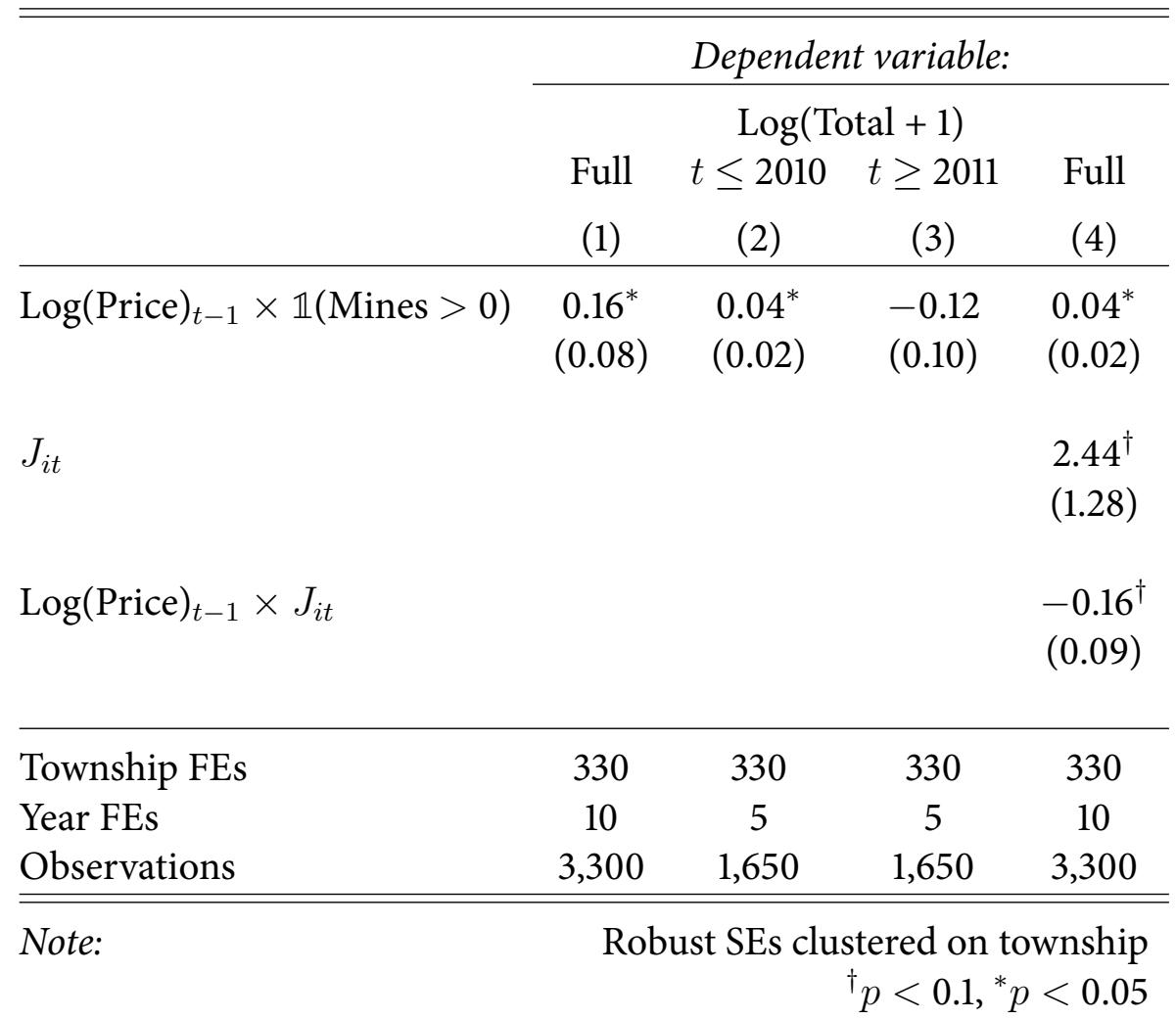

Notes: Columns 1-3: OLS models using the specification from equation 2; column 4: specification from equation 3. $J_{i t}$ is an indicator for jade-mining areas post-2010. Standard errors clustered at the township level are shown in parentheses. The outcome is the log of total events (see Section 4).

after incorporating price changes, we see a sharp increase in conflict in the post-transition period consistent with our earlier results. $^{32}$

\subsection{Potential Drivers of Conflict in Kachin State}

Sun (2014) observes that "the fact that armed conflict broke out three months after the inauguration of the Thein Sein government lends credence to the belief that there was a causal relationship between the political change and the armed conflict." Yet, our account is not on the only explanation

\footnotetext{
${ }^{32} \mathrm{We}$ are reticent to read much into the negative coefficient on price in the post-transition period, as it is driven by 2014, a year in which violence declined just after jade prices had dramatically increased.
} 
for why the Tatmadaw resumed hostilities in Kachin State following the political transition. ${ }^{33}$

First, some blamed fighting on the Myitsone Dam, a massive joint-venture between the China Power Investment Corporation and Myanmar's government. The project's environmental and social impacts inspired dissent; the government offensive was allegedly intended to secure the investment project. A conservationist interviewed by The Guardian summarizes this viewpoint: "The conflict is closely related to the dams. The government has sent in troops because it wants to gain control of a region [Kachin State] that hosts major Chinese investments in hydropower" (qtd. in Watts 2011).

Nothing in the data indicates that conflict near the dam is driving our results. Myitkyina Township, the site of the Myitsone Dam, does not contain any jade mines according to the GEMDATA. ${ }^{34}$ Thus, our estimates do not conflate the effects of the project and mining activity. Our results are robust to omitting Myitkyina Township from the sample. If anything, the three conflicts that occur in Myitkyina between 2011 and 2013 attenuate our estimates.

Second, a year prior to the political transition, in 2010 the KIA/KIO refused to transform into a Border Guard Force, a sub-division of the Tatmadaw. At the same time, the KIA/KIO called for a federal state (The Irrawaddy 2014). Some sources suggest that by 2009 Than Shwe, angered by these demands for greater autonomy, had already decided to resume fighting the KIA/KIO (Transnational Institute 2013,5). A variant of this argument suggests that the Tatmadaw intended for their offensive against the KIA/KIO to intimidate other ethnic armed organizations outside of Kachin State.

Both claims suggest that Kachin State in general, rather than jade-mining areas specifically, should have seen a sharp increase in conflict. Our results, however, are robust to the inclusion of state $\times$ year fixed effects (i.e., dummies for every state and year), indicating that our estimates do

${ }^{33}$ For violence to serve the strategic purpose we posit, there needs to be some ambiguity around the Tatmadaw's motives. If there are no alliterative accounts and everyone believes the violence to be theater that serves no security purpose, the civilian government is unlikely to be deterred.

${ }^{34}$ The impacts of the dam are obviously not delineated by township boundaries; nonetheless, most accounts suggest that conflict related to the dam was near the project site. 
not simply reflect an uptick in violence in Kachin State after the transition (see Table A.6). Put more simply, restricting attention to only Kachin State, we still find that conflict increases more sharply after the political transition in jade-mining areas relative to townships without mines.

We recognize that this is not conclusive evidence: KIA/KIO personnel might have been stationed in jade-mining areas; hence, it could appear that fighting occurred near mines simply by virtue of prior troop placements. Before the political transition, there was no correlation between the number of mines and conflicts across townships in Kachin State, suggesting that past confrontations were not concentrated near jade mining. This is consistent with Kramer's (2009) pre-transition map, which suggests that KIA/KIO control did not extend to the jade-mining townships of Kachin, including Hpakant, Mohnyin, or Waingmaw. Rather, the group's strongholds, including its headquarters in Laiza, are located near the Chinese border. Global Witness's (2015, 90-93) interviews with KIA/KIO officials also indicate that the group had agreed to pull out of jade-mining areas during the ceasefire period: "From a KIA/KIO perspective the government had breached the ceasefire [in 2011] and this mean that any agreement to stay out of the mining areas and not [directly] tax the companies was null and void." After fighting broke out, the group expressed a desire "to resume control and management of the jade business," intending to reclaim authority ceded in its informal revenue-sharing agreement with the Tatmadaw. Despite this primary evidence, with no pre-transition data on the location of KIA brigades, we cannot pin down where these troops were stationed when the Tatmadaw launched its operations in 2011.

Finally, Brenner (2015) argues that "ceasefire capitalism" - the period of relative peace in Kachin State that enabled the exploitation of the region's natural resources - enriched military elites and KIA/KIO leaders but did little to benefit the rest of the population. ${ }^{35}$ This generated resentment among the rank and file of the KIA/KIO. And after these lower ranking officers seized

${ }^{35}$ This work is an extension of Woods (2011), who argues that the Burmese military regime cultivated ceasefire capitalism by appropriating global markets, trans-national business people, and ethnic elites in order to extend authority into the ethnic upland frontier areas. 
power, they adopted a more confrontational stance vis-a-vis the Tatmadaw. Without disputing this account, it does not explain (1) why conflict within Kachin State conflict was concentrated in jademining townships; (2) why conflict ticks up so suddenly after the political transition; and (3) why the KIA/KIO's internal politics would induce more one-sided attacks on civilians by the Tatmadaw.

\section{Conclusion}

Facing a democratic transition, we argue that the military can maintain its control of valuable rents by stoking violence. The logic, while perverse, is quite simple: an ascendant civilian government relies on security forces to put down domestic unrest and external threats and is reluctant to strip military elites of their authority over conflict-ridden regions.

We find evidence of this dynamic in Myanmar, a country transitioning from four decades of military rule. Prior to democratization, the military government peacefully colluded with rebel groups to split profits from jade mining and smuggling - a sector worth roughly half of Myanmar's GDP. However, fearing that the new civilian government will assume control of jade-mining areas and the associated rents, the military gins up unrest in mining townships to deter the development of an alternative authority.

Using geo-coded data on armed conflict and jade mining, we show (1) that conflicts involving the Tatmadaw in jade-mining townships increased dramatically in the wake of the country's political transition (relative to violence in other parts of the country over the same period); and (2) that prior to democratization, jade-mining areas remained peaceful despite increases in the value of jade exports, which some theories suggest should have induced predation by greedy rebels.

Our findings point to a major challenge facing Myanmar and other countries transitioning from military to civilian rule. Like any incumbent, the military uses the strategies at its disposal to retain power during political transitions; unlike other incumbents, the strategies available to the military include inciting large-scale armed conflicts. This does not bode well for the consolidation of democracy and peace. Global Witness $(2015,41)$ offers this bleak assessment: "In Myanmar's 
current political landscape, money is power. Everyone wishing to see peace and genuine democracy in Myanmar should urgently consider the implications of allowing hundreds of millions of dollars a year [in resource rents] to be siphoned off by some of the most determined and ruthless opponents of reform." Unfortunately, this paper and past research on democratic transitions from military rule suggest that unseating both ruthless and well-armed opponents of reform may outstrip the capacity of a new civilian government. 


\section{References}

110th US Congress. 2008. “Tom Lantos Block Burmese JADE (Junta’s Anti-Democratic Efforts) Act of 2008." congress.gov .

Acemoglu, Daron, Davide Ticchi, and Andrea Vindigni. 2010. “A Theory of Military Dictatorships." American Economic Journal: Macroeconomics 2 (1): 1-42.

Acemoglu, Daron, and James A Robinson. 2006. Economic Origins of Dictatorship and Democracy. Cambridge University Press.

Barany, Zoltan. 2016. "Armed Forces and Democratization in Myanmar: Why the US Military Should Engage the Tatmadaw." Center for Strategic and International Studies .

Brenner, David. 2015. "Ashes of co-optation: from armed group fragmentation to the rebuilding of popular insurgency in Myanmar." Conflict, Security \& Development 15 (4): 337-358.

Burbidge, John B, Lonnie Magee, and A Leslie Robb. 1988. “Alternative transformations to handle extreme values of the dependent variable." Journal of the American Statistical Association 83 (401): 123-127.

Callahan, Mary P. 2003. Making Enemies: War and State Building in Burma. Cornell University Press.

Callahan, Mary P. 2012. “The Generals Loosen Their Grip.” Journal of Democracy 23 (4): 120-131.

Callahan, Mary P, and Donald K Emmerson. 1998. Political Legacies and Prospects for Democratic Development in Southeast Asia: Burma and Indonesia. Technical report.

Chang, Wen-Chin. 2004. "Guanxi and regulation in networks: The Yunnanese jade trade between Burma and Thailand, 1962-88." Journal of Southeast Asian Studies 35 (03): 479-501.

Chang, Wen-Chin. 2006. “The Trading Culture of Jade Stones Among the Yunnanese in Burma and Thailand, 1962-88." Journal of Chinese Overseas 2 (2): 269-293.

Chen, Xi, and William D Nordhaus. 2011. "Using luminosity data as a proxy for economic statistics." Proceedings of the National Academy of Sciences 108 (21): 8589-8594. 
Collier, Paul, and Anke Hoeffler. 2002. “Greed and Grievance in Civil War.” CSAE Working Paper Series.

Croicu, Mihai, and Ralph Sundberg. 2015. UCDP GED Codebook version 4.0. Department of Peace and Conflict Research Uppsala University.

Dal Bó, Ernesto, and Pedro Dal Bó. 2011. “Workers, Warriors, and Criminals: Social Conflict in General Equilibrium." Journal of the European Economic Association 9 (4): 646-677.

Dapice, David, and Xuan Thanh Nguyen. 2013. Creating a Future: Using Natural Resources for New Federalism and Unity. Technical report.

Diamond, Larry. 1997. "Is the Third Wave of Democratization Over? an Empirical Assessment." Working Paper.

URL: https : //www3.nd.edu/ kellogg/publications/workingpapers/WPS/236.pdf

Doll, Christopher N H, Jan-Peter Muller, and Jeremy G Morley. 2006. "Mapping regional economic activity from night-time light satellite imagery." Ecological Economics 57 (1): 75-92.

Dube, Oeindrila, and Juan F Vargas. 2013. "Commodity Price Shocks and Civil Conflict: Evidence from Colombia." The Review of Economic Studies 80 (4): 1384-1421.

Economist, The. 2013. “Democracy on prescription.” The Economist.

Fearon, James D. 1995. “Rationalist explanations for war.” International Organization 49 (03): 379414.

Feaver, Peter D. 1996. “The Civil-military Problematique: Huntington, Janowitz, and the Question of Civilian Control.” Armed Forces \& Society 23 (2): 149-178.

Fergusson, Leopoldo, James A Robinson, Ragnar Torvik, and Juan F Vargas. 2014. “The Need for Enemies.” The Economic Journal 126 (June): 1018-1054.

Finer, Samuel Edward. 1962. The Man on Horseback: The Role of the Military in Politics. Pall Mall Press.

Floter, Annegret, Paivi Lujala, and Jan Ketil Rod. 2005. The Gemstone Dataset Codebook.

Geddes, Barbara, Erica Frantz, and Joseph G Wright. 2014. “Military Rule.” Annual Review of Polit- 
ical Science pp. 147-162.

Geddes, Barbara, Joseph Wright, and Erica Frantz. 2014. “Autocratic Breakdown and Regime Transitions: A New Data Set." Perspectives on Politics 12 (2): 313-331.

Gledhill, John. 2012. “Competing for Change: Regime Transition, Intrastate Competition, and Violence." Security Studies 21 (1): 43-82.

Global Witness. 2015. Jade: Myanmar's “Big State Secret”. Technical report.

Global Witness. 2016. "Myanmar government commits to jade reform.”

URL: https://www.globalwitness.org/en/press-releases/ myanmar-government-announces-ground-breaking-reforms-toxic-jade-business/

Global Witness. 2017. Cursed Treasure: Jade Riches, Deadly Conflict and Prospects for Peace in Myanmar. Technical report.

Gravers, Mikael, and Flemming Ytzen. 2014. Burma/Myanmar: Where Now? NIAS Press.

Haggard, Stephan, and Robert R Kaufman. 1995. The political economy of democratic transitions. Princeton University Press.

Hagopian, Frances. 1990. ““'Democracy by Undemocratic Means”? Elites, Political Pacts, and Regime Transition in Brazil." Comparative Political Studies 23 (2): 147-170.

Hainmueller, Jens. 2011. "Entropy Balancing for Causal Effects: A Multivariate Reweighting Method to Produce Balanced Samples in Observational Studies .” Political Analysis .

Herbst, Jeffrey. 2000. States and Power in Africa. Princeton, NJ: Princeton University Press.

Hijmans, Robert J, Susan E Cameron, Juan L Parra, Peter G Jones, and Andy Jarvis. 2005. “Very high resolution interpolated climate surfaces for global land areas." International Journal of Climatology 25 (15): 1965-1978.

Hughes, Richard W, Olivier Galibert, George Bosshart, Fred Ward, O Thet, Mark Smith, T T Sun, and George E Harlow. 2000. “Burmese Jade: The Inscrutable Gem.” Gems \& Gemology 36 (1): $2-26$.

Human Rights Watch. 2011. “Burma: Army Committing Abuses in Kachin State." Human Rights 
Watch.

URL: https : //www.hrw.org/news/2011/10/18/burma-army-committing-abuses-kachin-state Huntington, Samuel P. 1957. The Soldier and the State: The Theory and Politics of Civil-military Relations. Harvard University Press.

Janowitz, Morris. 1961. The Professional soldier: A Social and Political Portrait. Free Press of Glencoe New York.

Jolliffe, Kim. 2015. “Ethnic Armed Conflict and Territorial Administration in Myanmar." The Asia Foundation .

URL: http: //asiafoundation.org/publications/pdf/1521

Jones, Lee. 2014. “Explaining Myanmar's regime transition: the periphery is central." Democratization 21 (5): 780-802.

Jonsson, Michael, Elliot Brennan, and Christopher O’Hara. 2016. “Financing War or Facilitating Peace? The Impact of Rebel Drug Trafficking on Peace Negotiations in Colombia and Myanmar.” Studies in Conflict \& Terrorism .

Keen, David. 2014. Useful Enemies: When Waging Wars is More Important Than Winning Them. Yale University Press.

Keller, Edmond J. 2004. "Understanding Conflicts in the Horn of Africa." In Exploring Subregional Conflict Opportunities for Conflict Prevention. Boulder: pp. 1-16.

Kingsbury, Damien. 2014. "Political Transition in Myanmar: Prospects and Problems." Asian Politics Policy 6 (3): 351-373.

Kramer, Tom. 2009. "Burma’s Cease-fires at Risk: Consequences of the Kokang Crisis for Peace and Democracy." Transnational Institute Peace \& Security Briefing .

Kyed, Helene Maria, and Mikael Gravers. 2014. "Non-state Armed Groups in the Myanmar Peace Process: What are the Future Options?" (7).

Lacina, Bethany, and Nils Petter Gleditsch. 2005. "Monitoring Trends in Global Combat: A New Dataset of Battle Deaths." European Journal of Population 21 (2-3): 145-166. 
Lintner, Bertil. 2013a. “A well-laid war in Myanmar." Asia Times .

URL: http://www .asia-pacific-solidarity.net/asiapacific/focus/at_ awelllaidwarinmyanmar_010213.htm

Lintner, Bertil. 2013b. “The Military’s Still in Charge.” Foreign Policy .

Lintner, Bertil. 2015. “Opposition Wins in Myanmar, But Military Still Holds the Reins.” Yale Global Online .

Linz, Juan J, and Alfred Stepan. 1996. Problems of Democratic Transition and Consolidation: Southern Europe, South America, and Post-Communist Europe. JHU Press.

Lujala, Paivi. 2009. "Deadly combat over natural resources: Gems, petroleum, drugs, and the severity of armed civil conflict." Journal of Conflict Resolution 53 (1): 50-71.

Montgomery, Jacob M, Brendan Nyhan, and Michelle Torres. 2018. "How Conditioning on Posttreatment Variables Can Ruin Your Experiment and What to Do about It." American Journal of Political Science 110 (3): 512.

Myoe, Maung A. 2009. Building the Tatmadaw: Myanmar Armed Forces Since 1948. Institute of Southeast Asian Studies.

Naing, Saw Yan. 2012. “Thousands Flee as Burma Army Attacks Jade Capital.” The Irrawaddy .

Naylor, Hugh. 2015. "Houthi rebels in Yemen eye oil-rich province, sparking fears of all-out civil war." The Washington Post.

Nyunt, Khin Maung. 1995. “History of Myanmar Jade Trade till 1938.” Traditions in Current Perspective: Proceedings of the Conference on Myanmar and Southeast Asian Studies pp. 15-17.

O’Donnell, Guillermo, Philippe C Schmitter, Laurence Whitehead, Cynthia J Arnson, and Abraham F Lowenthal. 1986a. Transitions from Authoritarian Rule: Latin America. Johns Hopkins University Press.

O’Donnell, Guillermo, Philippe C Schmitter, Laurence Whitehead, Cynthia J Arnson, and Abraham F Lowenthal. 1986b. Transitions from authoritarian rule: Tentative conclusions about uncertain democracies. Johns Hopkins University Press. 
Özbudun, Ergun. 2000. Contemporary Turkish politics: challenges to democratic consolidation. Lynne Rienner Publishers.

Przeworski, Adam. 1991. Democracy and the Market: Political and Economic Reforms in Eastern Europe and Latin America. Cambridge University Press.

Reno, William. 1999. Warlord Politics and African States. Lynne Rienner Publishers.

Scott, James C. 2009. The Art of Not Being Governed. Yale University Press.

Shor, Russell. 2013. As Jadeite Prices Soar, So Does Supply Uncertainty. Technical report.

Slater, Dan. 2014. “The elements of surprise: assessing Burma’s double-edged détente." South East Asia Research 22 (2): 171-182.

Smith, Martin. 2007. State of strife: the dynamics of ethnic conflict in Burma. Vol. 36 Institute of Southeast Asian Studies.

Sone, Nyein Pyae. 2013. "The Union of Myanmar Economic Holdings Also Has to Pay." The Irrawaddy.

Sun, Yun. 2014. "China, the United States and the Kachin conflict." Washington DC: Stimson p. 7.

The Irrawaddy. 2014. “A Chronology of Myanmar's Kachin Conflict." The Irrawaddy.

Transnational Institute. 2013. “The Kachin Crisis: Peace Must Prevail.” Burma Policy Briefing .

Ulmer, Alexander, and Deisy Buitrago. 2017. "New Venezuela oil boss to give military more PDVSA posts." Reuters .

Vanden Eynde, Oliver. 2015. "Mining Royalties and Incentives for Security Operations: Evidence from India’s Red Corridor." PSE Working Papers .

URL: https://halshs . archives-ouvertes.fr/halshs-01245496/document

Watts, Jonathan. 2011. "Dozens killed in Burma amid clashes over Chinese dams." The Guardian .

Weidmann, Nils B, and Sebastian Shutte. 2016. "Using Night Light Emissions for the Prediction of Local Wealth." Journal of Peace Research pp. 1-16.

Woods, Kevin. 2011. "Ceasefire Capitalism: Military-Private Partnerships, Resource Concessions and Military-State Building in the Burma-China Borderlands." Journal of Peasant Studies 38 (4): 
$747-770$.

Zaw, Hnin Yadana. 2015. "Chinese jade miners in overdrive ahead of new Myanmar government." Reuters .

Zin, Min, and Brian Joseph. 2012. “The Opening in Burma.” Journal of Democracy 23 (4): 104-119. 


\section{Supporting Information}

Strategic Violence during Democratization:

Evidence from Myanmar

Following text to be published online.

\section{Contents}

A.1 Summary Statistics

A.2 Placebo Results

A.4 Including Township-Specific Time-Trends

A.5 Re-weighting to Balance Pre-Treatment Measures

A.6 Including State $\times$ Year Fixed Effects

A.7 Conflict in Townships under Ceasefires

A.8 Inverse Hyperbolic Sine Transformation

A.9 Using Raw Counts as Dependent Variable

A.10 Null Effect on Non-State Conflict

A.11 Binary Measure of Mining Activity

A.12 Substituting Chinese Luxury Demand for Jade Prices 
A.14 UCDP Event Descriptions 


\section{A.1. Summary Statistics}

Table A.1: Summary Statistics

\begin{tabular}{lccccc}
\hline \hline Statistic & $\mathrm{N}$ & Mean & St. Dev. & Min & Max \\
\hline Total & 3,300 & 0.129 & 1.240 & 0 & 56 \\
State-based & 3,300 & 0.082 & 1.051 & 0 & 53 \\
One-sided & 3,300 & 0.042 & 0.500 & 0 & 15 \\
Non-state & 3,300 & 0.005 & 0.092 & 0 & 3 \\
\# Mines & 3,300 & 0.030 & 0.300 & 0 & 5 \\
Log(Jade Price) $t-1$ & 3,300 & 11.821 & 1.145 & 10.309 & 13.743 \\
Log(Chinese Luxury Demand) $)_{t-1}$ & 3,300 & 6.593 & 0.499 & 5.690 & 7.188 \\
Year & 3,300 & $2,010.500$ & 2.873 & 2,006 & 2,015 \\
Avg. Nightlights & 2,632 & 5.764 & 15.642 & 0.000 & 63.000 \\
Median Altitude & 3,290 & 358.816 & 458.529 & 1.000 & $2,384.000$ \\
\hline
\end{tabular}




\section{A.2. Placebo Results}

We estimate equation 1 using data from the pre-transition period (1995-2010), and coding $D_{i t}$ using years prior to the actual transition. These "placebo" (i.e., fake) transitions consistently generate null findings, indicating that mining and non-mining areas do not follow divergent trends prior to 2011. The right-most result uses the actual transition and is extremely similar to the coefficient from Table 1, model 1. The point estimates differ very slightly, as the model in the figure uses more data from the pre-transition period.

Figure A.1: Placebo vs. Real Results

DV: $\log ($ Total +1$)$

$$
\rightarrow \text { Real - Placebo }
$$

$0.3-$

0.2

คิ

$0.1-$

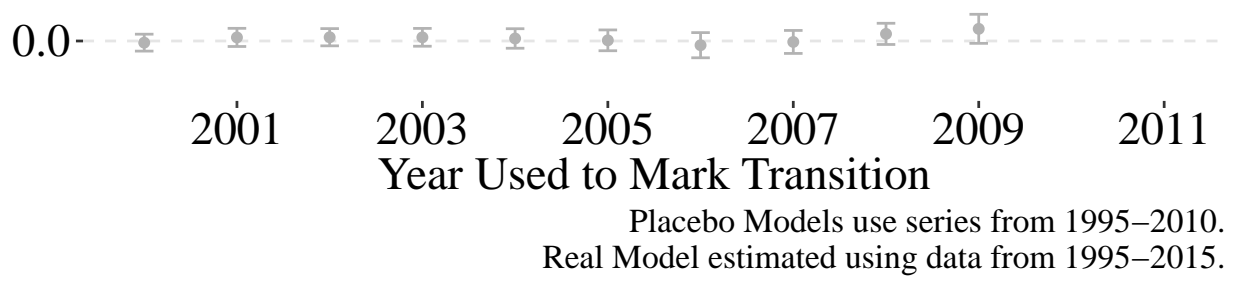




\section{A.3. Military-Owned Entities Targeted under US JADE Act}

In July 2008, the United States enacted the Tom Lantos Block Burmese JADE Act. ${ }^{36}$ The bill notes that Myanmar's junta owned much of Myanmar's jade sector, which was a major revenue source for the military regime. The purported goal of the legislation was "to impose sanctions on officials of the State Peace and Development Council in Burma, ... [and] to prohibit the importation of gemstones from Burma, or that originate in Burma."

To implement the JADE Act, the US Department of the Treasury's Office of Foreign Assets Control (OFAC) began including individuals and companies linked to the jade trade on their list of "Specially Designated Nationals" (SDNs), who are sanctioned by US law. We reviewed the list of Burmese SDNs from the JADE Act's passage until the 2011 transition and found thirteen major entities. (Table A.2 collapses related firms and individuals into a single entity.) Of the thirteen entities sanctioned under the JADE Act, military officials had a major ownership stake in twelve.

Table A.2: Burmese Specially Designated Nationals

\begin{tabular}{llll} 
Main Individual & $\begin{array}{l}\text { Year } \\
\text { Added }\end{array}$ & $\begin{array}{l}\text { Military } \\
\text { Link }\end{array}$ & Related Entities \\
\hline Aung, Dagon Win & 2009 & Yes & Dagon International Limited; Dagon Timber Limited \\
Te Za & 2009 & Yes & Espace Avenir \\
Cecilia Ng/Steven Law & 2009 & No & Golden Aaron Pte. Ltd. (plus 9 associated companies) \\
Zaw Zaw & 2009 & Yes & Max Myanmar companies (plus 12 associated companies) \\
Saw Tun & 2008 & Yes & Ko, Daw Myint Myint \\
Ye Myint & 2008 & Yes & Myint, Daw Tin Li \\
Nyan Win & 2008 & Yes & Soe, Daw Myint Myint \\
Shwe Mann & 2008 & Yes & Thet, Daw Khin Lay \\
Aung Thet Mann & 2008 & Yes & Ayer Shwe Wah Company Ltd. \\
U Kyaw Thein & 2008 & Yes & Myanmar Aviation Export; Pavo Aircraft Leasing Pte. Ltd. \\
Thi Ha & 2008 & Yes & Htoo Group of Companies \\
Pye Phyo Tay Za & 2008 & Yes & Air Bagan Holdings Pte. Ltd.
\end{tabular}

\footnotetext{
${ }^{36}$ https://www.treasury.gov/resource-center/sanctions/Documents/pl110_286_ jade_act.pdf
} 


\section{A.4. Including Township-Specific Time-Trends}

To rule out concerns about secular upward trends in conflict in mining townships (or declines in non-mining areas), we include township-specific linear trends in the model. Relative to the results reported in Table 1, the coefficients increase in magnitude.

Table A.3: Effect of Political Transition on Violence in Jade Townships (Includes Township-Specific Time-Trends)

\begin{tabular}{lccc}
\hline \hline & \multicolumn{3}{c}{ Dependent variable: } \\
\cline { 2 - 4 } & $\log ($ Total + 1) & $\log ($ State-Based + 1) & $\log ($ One-sided + 1) \\
& $0.289^{*}$ & $0.198^{*}$ & $(3)$ \\
\hline \# Mines $\times$ Post-2010 $\left(D_{i t}\right)$ & $(0.054)$ & $(0.058)$ & $0.164^{*}$ \\
& & & $0.028)$ \\
\hline Township FEs & 330 & 330 & 330 \\
Year FEs & 10 & 10 & 10 \\
Township Time-Trends & $\checkmark$ & $\checkmark$ & $\checkmark$ \\
Observations & 3,300 & 3,300 & 3,300 \\
\hline \hline
\end{tabular}

Note:

Robust SEs clustered on township; ${ }^{\dagger} p<0.1,{ }^{*} p<0.05$

Notes: OLS models using the specification from equation 1, including township-specific trends. Standard errors clustered at the township level are shown in parentheses. The dependent variable is the log of total events, state-based events, and one-sided government events (see Section 4). 


\section{A.5. Re-weighting to Balance Pre-Treatment Measures}

We pre-process our data using the entropy balancing algorithm developed by Hainmueller (2011). By re-weighting based on on altitude, as well as pre-treatment measures of economic development and conflict, we manufacture a balanced sample of control (non-mining) townships to provided a better prediction of the counterfactual trend in mining areas. While we have to dichotomize our mining variable to implement this routine, our findings remain qualitatively similar.

Table A.4: Balance Table after Pre-Processing

\begin{tabular}{rccc}
\hline \hline & Treatment Mean & Control Mean & p-value \\
\hline Median Altitude & 748.667 & 748.366 & 0.999 \\
Avg. Nightlights (1995-2000) & 0.166 & 0.175 & 0.979 \\
Avg. Nightlights $(2001-2005)$ & 0.159 & 0.167 & 0.980 \\
$\log \{$ Events +1$\}(1995-2000)$ & 0 & 0 & 0.968 \\
$\log \{$ Events +1$\}(2001-2005)$ & 0 & 0 & 0.972 \\
$\log \{$ One-sided +1$\}(1995-2000)$ & 0 & 0 & 0.970 \\
$\log \{$ One-sided +1$\}(2001-2005)$ & 0 & 0 & 0.978 \\
$\log \{$ State-based +1$\}(1995-2000)$ & 0 & 0 & 0.983 \\
$\log \{$ State-based +1$\}(2001-2005)$ & 0 & 0 & 0.983 \\
\hline
\end{tabular}

Notes: We dichotomize observations into mining or non-mining and then use entropy balancing to re-weight control (non-mining) observations. 
Table A.5: Effect of Political Transition on Violence in Jade Townships After Pre-Processing Data with Entropy Balancing

\begin{tabular}{lccc}
\hline \hline & \multicolumn{3}{c}{ Dependent variable: } \\
\cline { 2 - 4 } & $\log ($ Total +1$)$ & $\log ($ State-Based + 1) & $\log ($ One-sided + $)$ \\
& $(1)$ & $(2)$ & $(3)$ \\
\hline$J_{i t}$ & $0.409^{\dagger}$ & $0.413^{*}$ & 0.140 \\
& $(0.221)$ & $(0.198)$ & $(0.101)$ \\
& $\mathrm{p}=0.065$ & $\mathrm{p}=0.037$ & $\mathrm{p}=0.165$ \\
\hline Township FEs & 329 & 329 & 329 \\
Year FEs & 10 & 10 & 10 \\
Observations & 3,290 & 3,290 & 3,290 \\
\hline \hline & & & \multirow{2}{*}{ Note: }
\end{tabular}

Notes: OLS models using the specification from equation 1, omitting the township-specific trends. $J_{i t}$ is an indicator for jade-mining areas post-2010. We re-weight the control observations to generate balance on the pre-treatment variables included in table A.4. Standard errors clustered at the township level are shown in parentheses. The dependent variable is the log of total events, statebased events, and one-sided government events (see Section 4). 


\section{A.6. Including State $\times$ Year Fixed Effects}

We allow for non-parametric time-trends by state by substituting state $\times$ year fixed effects for the year fixed effects in equation 1 . This rules out any time-varying, state-specific confounds, such as changes that affect the entirety of Kachin State.

Table A.6: Effect of Political Transition on Violence in Jade Townships

\begin{tabular}{lccc}
\hline \hline & \multicolumn{3}{c}{ Dependent variable: } \\
\cline { 2 - 4 } & $\log ($ Total + 1) & $\log ($ State-Based + 1) & $\log ($ One-sided + 1) \\
& $(1)$ & $(2)$ & $(3)$ \\
\hline \# Mines $\times$ Post-2010 $\left(D_{i t}\right)$ & $0.212^{*}$ & $0.169^{*}$ & $0.107^{*}$ \\
& $(0.029)$ & $(0.026)$ & $(0.020)$ \\
\hline Township FEs & & & 330 \\
State $\times$ Year FEs & 330 & 330 & 150 \\
Observations & 150 & 150 & 3,300 \\
\hline \hline
\end{tabular}

Note:

Robust SEs clustered on township; ${ }^{\dagger} p<0.1,{ }^{*} p<0.05$

Notes: OLS models using the specification from equation 1 . We substitute State $\times$ Year fixed effects for the year fixed effects. Standard errors clustered at the township level are shown in parentheses. The dependent variable is the log of total events, state-based events, and one-sided government events (see Section 4). 


\section{A.7. Conflict in Townships under Ceasefires}

We use an early release of data compiled by the Asia Foundation for its Township Development Indicators to identify areas covered by ceasefire agreements between ethnic armed organizations and the Tatmadaw signed in or before 2011. We then assess whether these areas experience a differential increase in violence following the political transition, substituting $D_{i t}$ for $\mathbb{1}$ (Ceasefire) $\times \mathbb{1}$ (Post2010) in equation 1.

Table A.7: Change in Conflict in Areas Previously Covered by Ceasefires

\begin{tabular}{lcccc}
\hline \hline & \multicolumn{4}{c}{ Dependent variable: } \\
\cline { 2 - 5 } & \multicolumn{4}{c}{$\log ($ Total +1$)$} \\
& $(1)$ & $(2)$ & $(3)$ & $(4)$ \\
\hline $\mathbb{1}($ Ceasefire $) \times$ Post-2010 & 0.040 & -0.001 & -0.048 & 0.015 \\
& $(0.082)$ & $(0.081)$ & $(0.091)$ & $(0.080)$ \\
& & & & Not Kachin \\
\hline Sample & Full & Non-Mining & Not 2015 \\
Township FEs & 330 & 324 & 312 & 330 \\
State $\times$ Year FEs & 150 & 150 & 140 & 149 \\
Observations & 3,300 & 3,240 & 3,120 & 3,245 \\
\hline \hline
\end{tabular}

Note:

Robust SEs clustered on township; ${ }^{\dagger} p<0.1,{ }^{*} p<0.05$

Notes: OLS models that interact the post-transition indicator with an indicator for whether a township was covered by a pre-transition ceasefire agreement. Standard errors clustered at the township level are shown in parentheses. The dependent variable is the log of total events (see Section 4).

Comparing these results to model 1 of Table A.6, we find no evidence that townships covered by earlier ceasefire agreements saw a larger increase in violence after the transition. When we exclude jade-mining areas (some of which were covered by the 1994 ceasefire agreement with the KIA/KIO), the coefficient flips sign.

Looking more closely at the data, a few townships in Shan state covered by prior ceasefire agreements see an uptick in violence after 2011. However, much of this violence occurs in 2015, several years after the transition. Excluding only observations from Shan State in 2015 further attenuates the coefficient, which is an order of magnitude smaller than the estimate from Table A.6. 


\section{A.8. Inverse Hyperbolic Sine Transformation}

Per Burbidge, Magee, and Robb (1988), we employ the hyperbolic sine transformation of our conflict data $\left(\operatorname{IHS}(y):=\log \left\{y+\left(y^{2}+1\right)^{1 / 2}\right\}\right)$. Like $\log (y+c)$, this function is defined at zero. Moreover, this transformation does not require us to add $c$ and, thereby, assume that all areas experience some level of conflict.

Table A.8: Effect of Political Transition on Violence in Jade Townships

\begin{tabular}{lccc}
\hline \hline & \multicolumn{3}{c}{ Dependent variable: } \\
\cline { 2 - 4 } & IHS(Total) & IHS(State-Based) & IHS(One-sided) \\
& $(1)$ & $(2)$ & $0.149^{*}$ \\
\# Mines $\times$ Post-2010 $\left(D_{i t}\right)$ & $\begin{array}{c}0.344^{*} \\
(0.041)\end{array}$ & $\begin{array}{c}0.287^{*} \\
(0.043)\end{array}$ & $(0.020)$ \\
& & & 330 \\
Township FEs & 330 & 330 & 10 \\
Year FEs & 10 & 10 & 3,300 \\
Observations & 3,300 & 3,300 & ${ }^{*}$ \\
\hline \hline Note: & Robust SEs clustered on township; ${ }^{\dagger} p<0.1,{ }^{*} p<0.05$
\end{tabular}

Notes: OLS models using the specification from equation 1. Standard errors clustered at the township level are shown in parentheses. The dependent variable is transformed using the inverse hyperbolic sine function applied to total events, state-based events, and one-sided government events (see Section 4). 


\section{A.9. Using Raw Counts as Dependent Variable}

Table A.9 shows the results from equation 1 using the raw count as the dependent variable.

Table A.9: Primary Results using Raw Counts

\begin{tabular}{|c|c|c|c|}
\hline & \multicolumn{3}{|c|}{ Dependent variable: } \\
\hline & $\begin{array}{l}\text { Total } \\
(1)\end{array}$ & $\begin{array}{c}\text { State-Based } \\
\text { (2) }\end{array}$ & $\begin{array}{c}\text { One-sided } \\
\text { (3) }\end{array}$ \\
\hline \# Mines $\times$ Post-2010 $\left(D_{i t}\right)$ & $\begin{array}{c}0.715^{*} \\
(0.067)\end{array}$ & $\begin{array}{c}0.497^{*} \\
(0.060)\end{array}$ & $\begin{array}{c}0.220^{*} \\
(0.029)\end{array}$ \\
\hline Township FEs & 330 & 330 & 330 \\
\hline Year FEs & 10 & 10 & 10 \\
\hline Observations & 3,300 & 3,300 & 3,300 \\
\hline
\end{tabular}

Notes: OLS models using the specification from equation 1. Standard errors clustered at the township level are shown in parentheses. The dependent variable is the count of total events, state-based events, and one-sided government events (see Section 4). 
Figure A.2: Conflicts in Jade-Mining and Other Townships before and after 2011
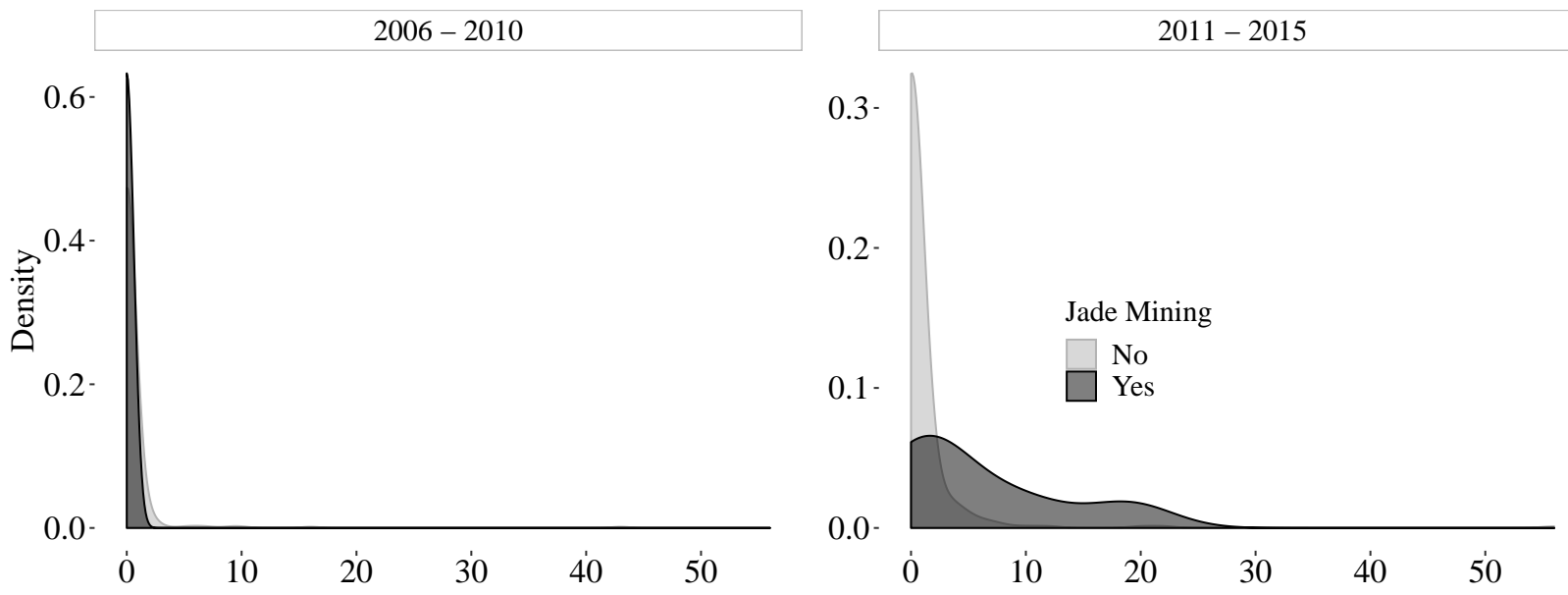

Sum of UCDP Events 


\section{A.10. Null Effect on Non-State Conflict}

Our argument implies that the uptick in violence relates to a proactive offensive by the military in their effort to retain control of the jade sector. While we find a differential increase in armed conflict events (particularly those involving government) in mining areas after the transition, we do not find a simultaneous increase in non-state conflict events. This both points to our preferred mechanism and suggests that the security situation in mining townships might have remained unchanged had the Tatmadaw never intervened.

Table A.10: Effect of Political Transition on Communal Conflict in Jade Townships

\begin{tabular}{lcc}
\hline \hline & \multicolumn{2}{c}{ Dependent variable: } \\
\cline { 2 - 3 } & \multicolumn{2}{c}{$\log ($ Total +1$)$} \\
& $(1)$ & $(2)$ \\
\hline \# Mines $\times$ Post-2010 $\left(D_{i t}\right)$ & $-0.001^{\dagger}$ & $-0.002^{\dagger}$ \\
& $(0.001)$ & $(0.001)$ \\
\hline Township FEs & 330 & 330 \\
Year FEs & 10 & 10 \\
Township Time-Trends & & $\checkmark$ \\
Observations & 3,300 & 3,300 \\
\hline \hline Note: & Robust SEs clustered on township \\
& \multicolumn{2}{c}{$p<0.1,{ }^{*} p<0.05$}
\end{tabular}

Notes: OLS models using the specification from equation 1, omitting the township-specific trends. Standard errors clustered at the township level are shown in parentheses. Dependent variable is the $\log$ of non-state events (see Section 4). 


\section{A.11. Binary Measure of Mining Activity}

Table A.11: Effect of Political Transition on Violence in Jade Townships

\begin{tabular}{lccc}
\hline \hline & \multicolumn{3}{c}{ Dependent variable: } \\
\cline { 2 - 4 } & $(1)$ & $(2)$ & $(3)$ \\
\hline $\mathbb{1}($ Mine $) \times$ Post-2010 & $0.475^{*}$ & $0.413^{*}$ & 0.140 \\
& $(0.220)$ & $(0.198)$ & $(0.101)$ \\
& & & $\log ($ State-Based +1$)$ \\
\hline Township FEs & 330 & 330 & 330 \\
Year FEs & 10 & 10 & 10 \\
Observations & 3,300 & 3,300 & 3,300 \\
\hline \hline Note: & \multicolumn{2}{c}{ Robust SEs clustered on township; ${ }^{\dagger} p<0.1,{ }^{*} p<0.05$}
\end{tabular}

Notes: OLS models using the specification from equation 1 , where we use a binary measure of mining activity to construct the interaction term rather than the number of mines. Standard errors clustered at the township level are shown in parentheses. The dependent variable is the count of total events, state-based events, and one-sided government events (see Section 4). 


\section{A.12. Substituting Chinese Luxury Demand for Jade Prices}

As Myanmar is a top producer of jade, one could be concerned that violence reduces supply and boosts jade prices. We exploit the fact that nearly all jade produced in Myanmar is exported to China. Given the importance of Chinese demand for jade prices, we substitute jade prices in models 2 and 3 with Chinese luxury sales - specifically, high-end car sales - to isolate variation in prices that is unrelated to local conflict. While we only estimate the reduced form, the implied exclusion restriction is that Chinese luxury demand does not affect conflict in Myanmar except through its effects on jade prices; we find no qualitative evidence questioning this assumption.

Figure A.3: Relationship between Jade Prices and Chinese Luxury Demand

$$
\text { Series: - Chinese Luxury Demand (x2) … Jade Price }
$$

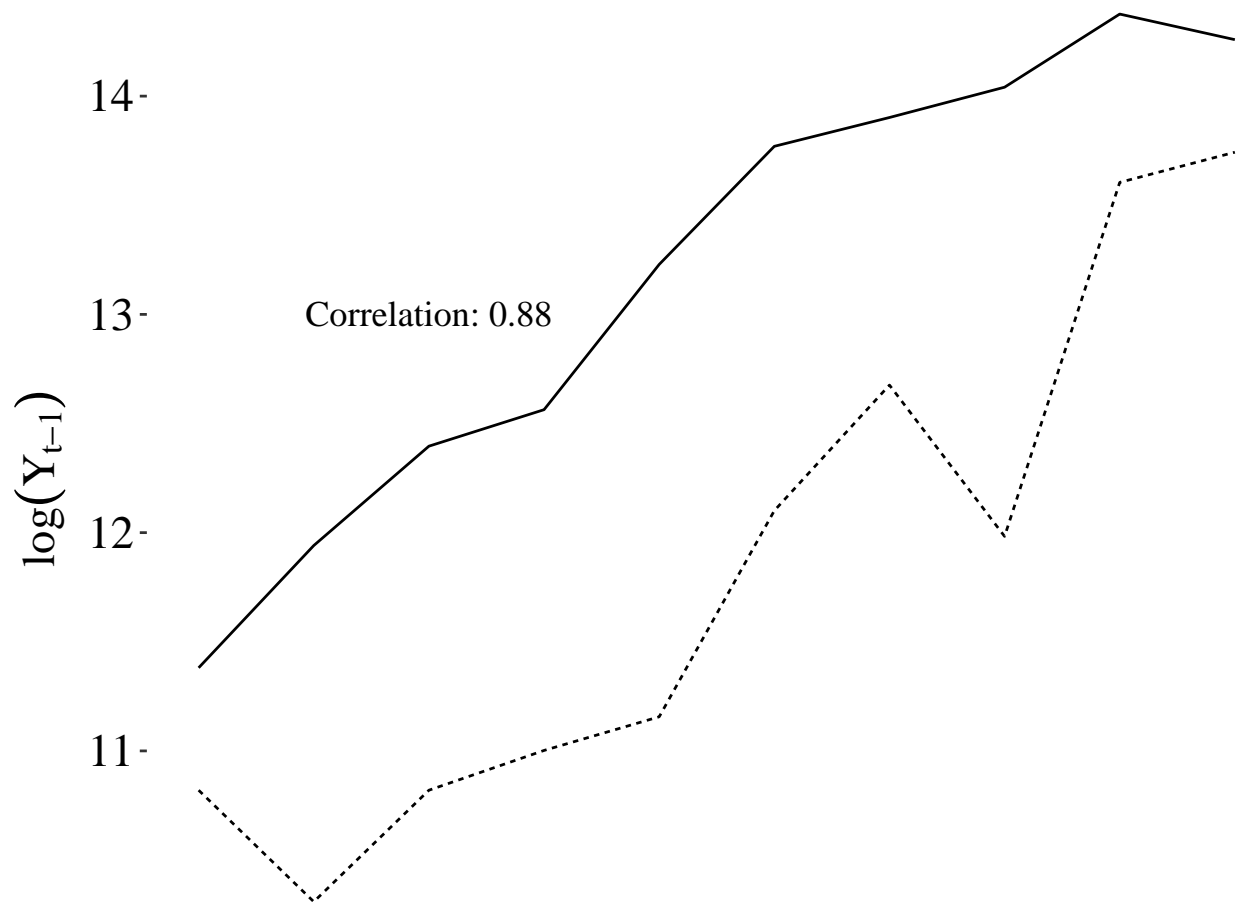

$10-$

$$
2007 \quad 2009 \quad 2011 \quad 2013
$$

Notes: This figure shows the trends in both jade prices and Chinese luxury demand (measured by high-end car sales). Both series have been logged and lagged one year. We multiply the Chinese luxury demand series by 2 to focus attention on the nearly parallel trends, rather than the (inconsequential) level differences. 
Figure A.3 first shows the striking correlation $(\rho=0.88)$ between Chinese luxury demand and jade prices. We then reproduce Table 2 but substitute our measure of Chinese luxury demand for jade prices. Despite a change in scale, the results remain the same.

Table A.12: Effect of Political Transition and Chinese Luxury Demand on Conflict in Jade Mining Areas

\begin{tabular}{|c|c|c|c|c|}
\hline & \multicolumn{4}{|c|}{ Dependent variable: } \\
\hline & \multicolumn{4}{|c|}{$\log ($ Total +1$)$} \\
\hline & $(1)$ & $(2)$ & (3) & $(4)$ \\
\hline $\log (\text { Chinese Car Sales })_{t-1} \times \mathbb{1}($ Mines $>0)$ & $\begin{array}{l}0.41^{*} \\
(0.18)\end{array}$ & $\begin{array}{l}0.03^{\dagger} \\
(0.02)\end{array}$ & $\begin{array}{l}-0.86 \\
(0.78)\end{array}$ & $\begin{array}{c}0.03^{\dagger} \\
(0.02)\end{array}$ \\
\hline$J_{i t}$ & & & & $\begin{array}{c}6.70 \\
(5.33)\end{array}$ \\
\hline $\log (\text { Chinese Car Sales })_{t-1} \times J_{i t}$ & & & & $\begin{array}{l}-0.89 \\
(0.73)\end{array}$ \\
\hline Township FEs & 330 & 330 & 330 & 330 \\
\hline Year FEs & 10 & 5 & 5 & 10 \\
\hline Observations & 3,300 & 1,650 & 1,650 & 3,300 \\
\hline
\end{tabular}

Notes: Columns 1-3: OLS models using the specification from equation 2; column 4: specification from equation 3. $J_{i t}$ is an indicator for jade-mining areas post-2010. Standard errors clustered at the township level are shown in parentheses. In all models we substitute Chinese luxury car sales for the jade price. Standard errors clustered at the township level are shown in parentheses. The outcome is the log of total events (see Section 4). 


\section{A.13. Potential Generalizable Cases}

We review recent and contemporary cases to determine a set of countries that meet our scope conditions, operationalizing the resources component through mining deposits.

First, we map all sub-provincial units - equivalent to counties in the US - using the Database of Global Administrative Areas (GADM). Second, we spatially merge in (1) point data on over 300,000 mineral deposits from the US Geological Survey's Mineral Resources Data System (MRDS), which is current as of 2011; and (2) data on armed conflict from the UCDP GED database, which covers 1989 to the present. This allows us to identify all autocracies containing districts with both natural resources and past conflict. ${ }^{37}$ The resulting list (see Table A.13) includes thirty countries, including Angola, Eritrea, and Ethiopia (all identified in our reading of the secondary literature), as well as our case, Myanmar. This exercise and secondary literature on other cases suggest that the dynamic we uncover is not unique to Myanmar.

In addition to the cases in Table A.13, there are others that have non-mining resources that coincide with insurgent activity, e.g. Chad and Yemen, as well as democratic cases that exhibit similar tendencies, e.g. Mali and eastern India.

\footnotetext{
${ }^{37}$ We operationalize autocracy as those countries with average Polity IV scores less than or equal to zero between 1989 and 2011.
} 
Table A.13: Autocracies Containing Districts with Natural Resources and Past Conflict

\begin{tabular}{|c|c|c|c|c|c|}
\hline Country & $\begin{array}{r}\text { MRDS } \\
\text { Total }\end{array}$ & $\begin{array}{r}\text { UCDP } \\
\text { Total }\end{array}$ & $\begin{array}{r}\text { GADM } 2 \\
\text { Units }\end{array}$ & $\begin{array}{l}\text { Units with } \\
\text { MRDS \& UCDP }\end{array}$ & $\begin{array}{r}\text { Polity Average } \\
(1989-2011)\end{array}$ \\
\hline Afghanistan & 33 & 13475 & 328 & 23 & -5 \\
\hline Algeria & 225 & 2625 & 1504 & 75 & -1 \\
\hline Angola & 13 & 1115 & 163 & 7 & -2 \\
\hline Cameroon & 11 & 61 & 58 & 1 & -4 \\
\hline China & 1035 & 32 & 344 & 10 & -7 \\
\hline Cote d'Ivoire & 21 & 244 & 33 & 5 & -2 \\
\hline Egypt & 198 & 425 & 343 & 12 & -5 \\
\hline Eritrea & 13 & 84 & 50 & 7 & -8 \\
\hline Ethiopia & 27 & 1287 & 79 & 9 & -3 \\
\hline Guinea & 30 & 69 & 34 & 7 & -2 \\
\hline Iran & 411 & 121 & 268 & 9 & -4 \\
\hline Iraq & 49 & 4438 & 102 & 25 & -6 \\
\hline Kyrgyzstan & 40 & 39 & 44 & 3 & -2 \\
\hline Laos & 244 & 13 & 142 & 7 & -7 \\
\hline Mauritania & 9 & 16 & 44 & 2 & -5 \\
\hline Morocco & 106 & 5 & 54 & 1 & -6 \\
\hline Myanmar & 80 & 883 & 63 & 17 & -7 \\
\hline Republic of Congo & 11 & 198 & 48 & 4 & -3 \\
\hline Rwanda & 4 & 401 & 30 & 4 & -5 \\
\hline Somalia & 160 & 3079 & 74 & 19 & 0 \\
\hline South Sudan & 1 & 889 & 45 & 1 & 0 \\
\hline Sudan & 18 & 952 & 80 & 6 & -6 \\
\hline Syria & 9 & 201 & 60 & 2 & -8 \\
\hline Tajikistan & 37 & 265 & 59 & 9 & -5 \\
\hline Tanzania & 65 & 6 & 183 & 1 & -2 \\
\hline Togo & 5 & 92 & 21 & 2 & -3 \\
\hline Uganda & 27 & 1132 & 166 & 7 & -3 \\
\hline United Arab Emirates & 1 & 1 & 195 & 1 & -8 \\
\hline Uzbekistan & 60 & 28 & 161 & 4 & -10 \\
\hline Zimbabwe & 257 & 45 & 60 & 16 & -4 \\
\hline
\end{tabular}




\section{A.14. UCDP Event Descriptions}

To give a sense of the events that we analyze in this paper, we have extracted the critical text from the underlying news articles for a number of the UCDP incidents.

- January 2013. "Burmese military admits airstrikes against Kachin" - https : //www . usatoday . com/story/news/world/2013/01/02/myanmar-airstrikes/1805663/ — "Burma's military acknowledged launching airstrikes against ethnic Kachin rebels in the north and said it captured a hilltop post...The military announcement highlights a seeming disconnect between the government and the military, which retains much power behind the scenes. An order late last year by Thein Sein to halt offensive operations against the Kachin was not honored in practice."

- October 2013. "Fighting Resumes in Southern Kachin State" - http: //www . kachinlandnews . $\mathrm{com} / \mathrm{p}=23885$ - "After several rounds of mortar shelling that also targeted an IDP camp and a boarding school in Mung Ding Pa village, Burmese army troops entered the village on Oct 22... A KLN source said that two villagers wounded and one died from an attack by Burmese army troops at Nam Hon village on Oct 15, just five days after KIO-Burmese government delegations met in Myitkyina. Fighting rage between KIA's 12th Battalion troops and Burmese army's combined troops near Saga Nam Hkum on Oct 23 at 10:30 am. More government troops are reported to have arrived in Namlim Pa village as fighting began yesterday."

- August 2014. “One Civilian Killed After TNLA, Govt Troops Clash” — https : //www . irrawaddy . com/news/burma/one-civilian-killed-tnla-govt-troops-clash.html - One civilian was shot dead and another hospitalized with a gunshot wound following a clash between government troops and the Ta'ang National Liberation Army (TNLA) on Monday morning in northern Shan State, according to the ethnic rebel group...The Burmese Army continues to move troops in the area, which the ethnic Palaung armed group lays claim to." 